University of South Florida

DIGITAL COMMONS

Digital Commons @ University of

@ UNIVERSITY OF SOUTH FLORIDA

South Florida

School of Geosciences Faculty and Staff

Publications

School of Geosciences

$1-2000$

\title{
Geologic Factors Controlling Patterns of Small-Volume Basaltic Volcanism: Application to a Volcanic Hazards Assessment at Yucca Mountain, Nevada
}

\author{
Charles B. Connor \\ Southwest Research Institute, cbconnor@usf.edu \\ John A. Stamatakos \\ Southwest Research Institute \\ David A. Ferrill \\ Southwest Research Institute \\ Brittain E. Hill \\ Southwest Research Institute \\ Goodluck I. Ofoegbu \\ Southwest Research Institute \\ Follow this and additional works at: https://digitalcommons.usf.edu/geo_facpub \\ See next page for additional authors \\ Part of the Earth Sciences Commons
}

\section{Scholar Commons Citation \\ Connor, Charles B.; Stamatakos, John A.; Ferrill, David A.; Hill, Brittain E.; Ofoegbu, Goodluck I.; Conway, Michael; Sagar, Budhi; and Trapp, John, "Geologic Factors Controlling Patterns of Small-Volume Basaltic Volcanism: Application to a Volcanic Hazards Assessment at Yucca Mountain, Nevada" (2000). School of Geosciences Faculty and Staff Publications. 1670. \\ https://digitalcommons.usf.edu/geo_facpub/1670}

This Article is brought to you for free and open access by the School of Geosciences at Digital Commons @ University of South Florida. It has been accepted for inclusion in School of Geosciences Faculty and Staff Publications by an authorized administrator of Digital Commons @ University of South Florida. For more information, please contact digitalcommons@usf.edu. 


\section{Authors}

Charles B. Connor, John A. Stamatakos, David A. Ferrill, Brittain E. Hill, Goodluck I. Ofoegbu, Michael Conway, Budhi Sagar, and John Trapp 


\title{
Geologic factors controlling patterns of small-volume basaltic volcanism: Application to a volcanic hazards assessment at Yucca Mountain, Nevada
}

\author{
Charles B. Connor, ${ }^{1}$ John A. Stamatakos, ${ }^{1}$ David A. Ferrill, ${ }^{1}$ Brittain E. Hill, ${ }^{1}$ \\ Goodluck I. Ofoegbu, ${ }^{1}$ F. Michael Conway, ${ }^{2}$ Budhi Sagar, ${ }^{1}$ and John Trapp ${ }^{3}$
}

\begin{abstract}
The proposed high-level radioactive waste repository at Yucca Mountain, Nevada, is located within an active volcanic field. Probabilistic volcanic hazard models for future eruptions through the proposed repository depend heavily on our understanding of the spatial controls on volcano distribution at a variety of scales. On regional scales, Pliocene-Quaternary volcano clusters are located east of the Bare Mountain fault.

Extension has resulted in large-scale crustal density contrast across the fault, and vents are restricted to low-density areas of the hanging wall. Finite element modeling indicates that this crustal density contrast can result in transient pressure changes of up to $7 \mathrm{MPa}$ at 40 $\mathrm{km}$ depth, providing a mechanism to generate partial melts in areas where mantle rocks are already close to their solidus. On subregional scales, vent alignments, including one alignment newly recognized by ground magnetic mapping, parallel the trends of high-dilation tendency faults in the Yucca Mountain region (YMR). Forty percent of vents in the YMR are part of vent alignments that vary in length from 2 to $16 \mathrm{~km}$. Locally, new geological and geophysical data show that individual vents and short vent alignments occur along and adjacent to faults, particularly at fault intersections, and leftstepping en echelon fault segments adjacent to Yucca Mountain. Conditions which formed these structures persist in the YMR today, indicating that volcanism will likely continue in the region and that the proposed repository site is within an area where future volcanism may occur. On the basis of these data the probability of volcanic disruptions of the proposed repository is estimated between $10^{-8} / \mathrm{yr}$ and $10^{-7} / \mathrm{yr}$.
\end{abstract}

\section{Introduction}

Volcanic hazard analyses are often required for facilities, such as nuclear power plants and high-level radioactive waste repositories, that must be constructed in areas of low geologic risk [International Atomic Energy Agency, 1997]. The proposed high-level radioactive waste repository at Yucca Mountain, Nevada, is one such facility. Plans call for this repository to isolate high-level radioactive waste for a time period of the order of $10^{4}-10^{5}$ years [e.g., Krauskopf, 1988; U.S. Nuclear Waste Technical Review Board, 1994; U.S. National Research Council, 1995]. Volcanic hazards associated with the repository stem from its location within a geologically active basaltic volcanic field that includes $\sim 40$ basaltic vents formed since 10.5 $\mathrm{Ma}$ and, notably, six cinder cones formed since 1 Ma that are located within $20 \mathrm{~km}$ of the site (Figures 1a and 1b) [Crowe et al., 1983; Connor and Hill, 1995; Fleck et al., 1996]. This Quaternary basaltic volcanism is deleterious because of the potential for small-volume basaltic eruptions through the repository that are capable of transporting waste into the environment. In order to effectively evaluate this hazard in light of the pro-

\footnotetext{
${ }^{1}$ Center for Nuclear Waste Regulatory Analyses, Southwest Research Institute, San Antonio, Texas.

${ }^{2}$ Department of Physical Sciences, Western Arizona College, Yuma.

${ }^{3}$ Office of Materials Safety and Safeguards, Division of Waste Management, U.S. Nuclear Regulatory Commission, Washington, D. C.

Copyright 2000 by the American Geophysical Union.

Paper number 1999JB900353.

0148-0227/00/1999JB900353\$09.00
}

posed longevity of the repository, an understanding of geologic factors that control volcanism on timescales of $10^{4}-10^{7}$ years is needed.

This paper describes the current geological and geophysical evidence for the role that crustal extension and crustal structures play in the development of basaltic volcanism in the Yucca Mountain region (YMR). General questions about the role of the crust in development of basaltic volcanic fields include the following: How does brittle deformation in the lithosphere influence the generation of small-volume basaltic magmas in the mantle? What role can specific geologic structures such as faults or shear zones play in the ascent and eruption of basalts? Therefore, what can be learned about likely locations of future eruptions based on the distribution of these structures? How does the interplay between local fault geometry and regional state of stress influence the location of individual volcanoes or the development and longevity of alignments of basaltic vents? In the YMR, basaltic volcanism, the structural geology, and geophysics of the region have been the topic of considerable study. Thus the YMR provides an excellent opportunity to investigate these general questions about development of basaltic volcanic fields in detail.

Previous investigations demonstrated that the recurrence rate of basaltic volcanism in the YMR is relatively low, on the order of 2-12 volcanic events per million years [Ho et al., 1991; Crowe, 1990; Crowe et al., 1992], that the most recent YMR eruptions occurred at Lathrop Wells volcano, at $\sim 0.08 \mathrm{Ma}$ [Heizler et al., 1999], and that YMR volcanic activity is spatially and temporally clustered [Connor and Hill, 1993, 1995]. As in 


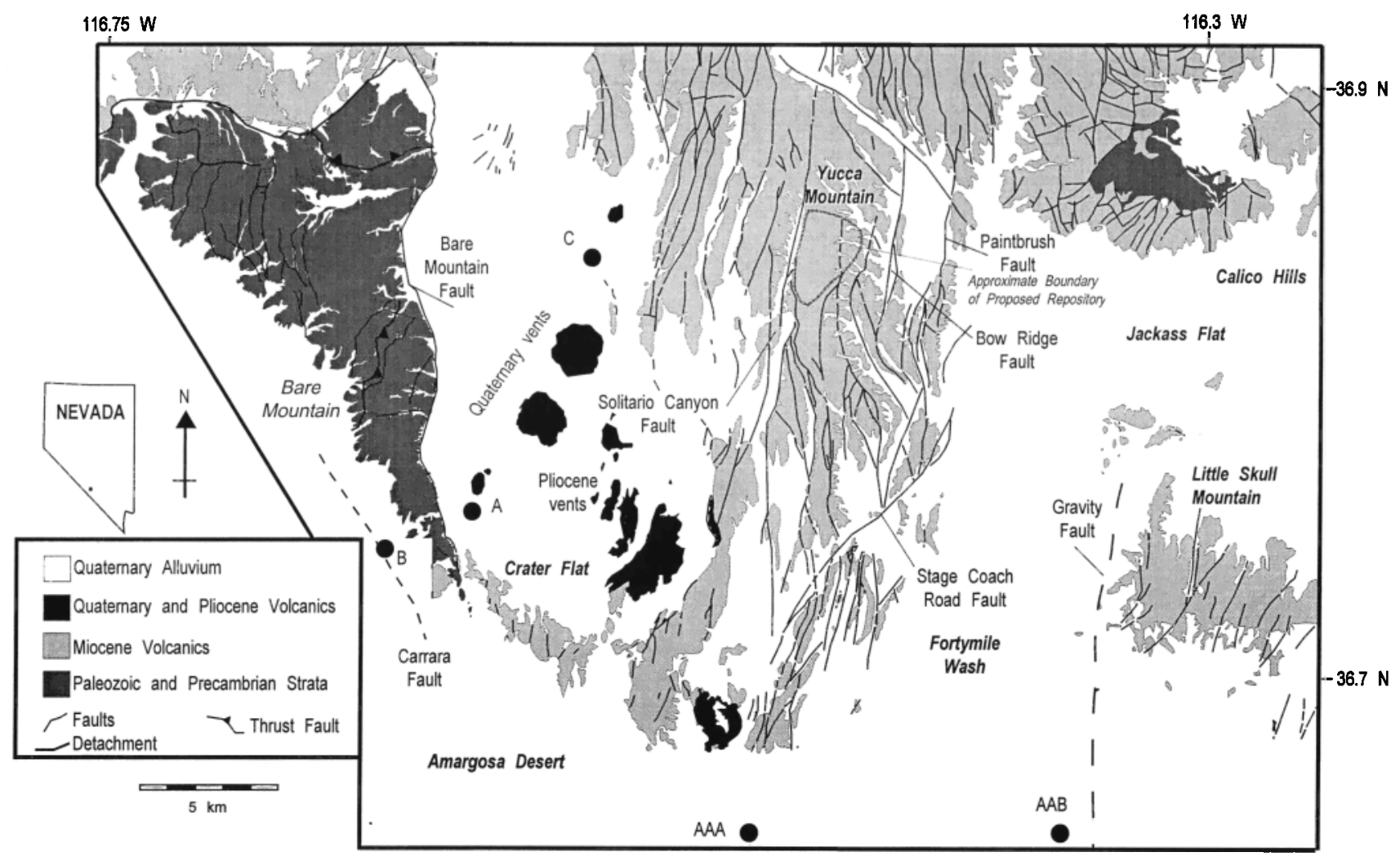

Figure 1a. Location and geologic setting of the proposed Yucca Mountain high-level radioactive waste repository. Geology is from Frizzell and Schulters [1990] and Day et al. [1997]. Locations of ground magnetic maps shown in Plate 3a-3d are indicated by labels A-C and AAA, respectively.

other basaltic volcanic fields, structure may influence the distribution of volcanism on several scales, from the alignment of volcanoes along faults to the localization of volcano clusters in structural basins. Furthermore, rates of basaltic magmatism may be related to changes in rates of extension [e.g., Bacon, 1982; Parsons and Thompson, 1991; Luhr et al., 1997; Wernicke et al., 1998]. In the YMR, tectonic controls on volcanism have been used to support both comparatively high and low estimates of the probability of basaltic eruptions at the proposed repository site [Crowe and Perry, 1989; Smith et al., 1990] relative to estimates that do not explicitly consider structure [Connor and Hill, 1995].

The influence of crustal structure on volcanism, therefore, is identified and investigated on three separate scales. First, on a regional scale, balanced geologic cross sections and gravity data are used to investigate and model the regional relationship between the distribution of basaltic volcanism and crustal extension. At this scale it appears that shifts in the locus of volcanism through time and the concentration of volcanic activity within specific areas of the YMR result predominantly from lithospheric melting in response to extension. This extension is also manifest in slip on major crustal faults during the Pliocene and Quaternary. The resulting pattern in vent distribution and relationship to major crustal structures provides a basis for the volcanic hazard assessment. Second, on a subregional scale, geologic field and ground magnetic data are used to identify and map alignments of basaltic volcanoes, one of which has been entirely buried by alluvium. These alignments all parallel mapped normal faults, especially those with orientations that tend to cause them to dilate in response to extension. Factors controlling alignment development, length, and

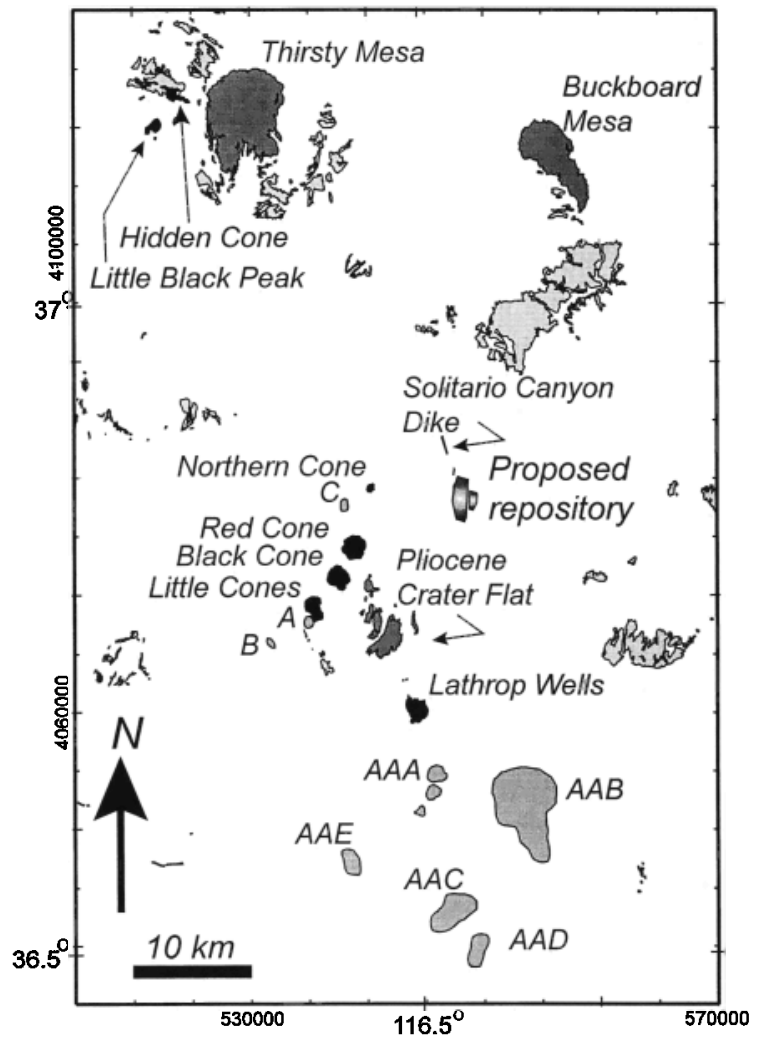

Figure 1b. Distribution of basaltic rocks in the YMR: light grey shading, Miocene; dark gray shading, Pliocene; black shading, Quaternary. Magnetic anomalies are shown in light grey shading, but only $\mathrm{AAB}$ is dated (Pliocene). 


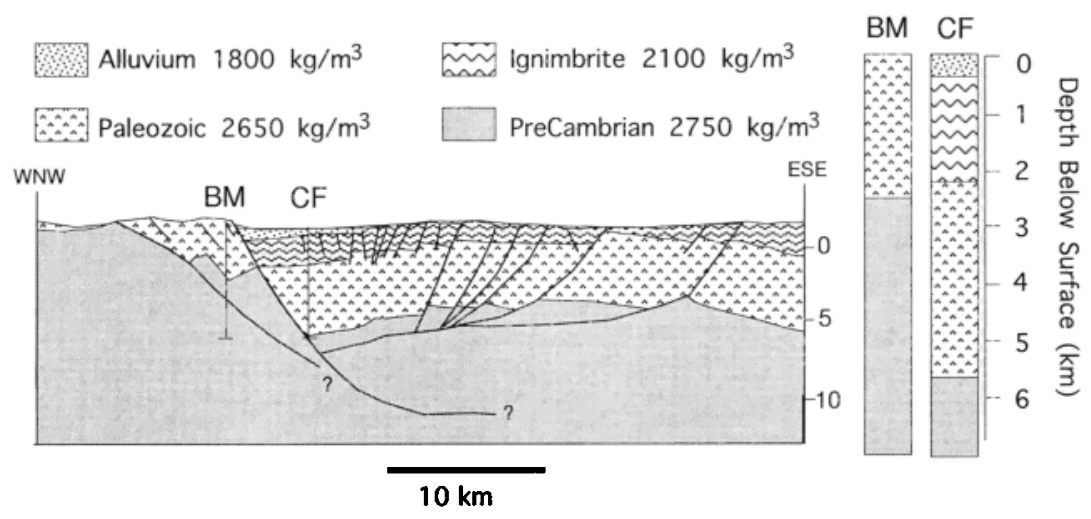

Figure 2. Balanced cross section across Bare Mountain, Crater Flat, and Yucca Mountain [Ofoegbu and Ferrill, 1998]. High-angle normal faults at Yucca Mountain intersect a detachment at depths between 5 and $10 \mathrm{~km}$. Such high-dilation tendency faults may serve as pathways for ascending magmas. This profile is used to estimate density differences between Crater Flat (CF) and Bare Mountain (BM) using density values for major units from McKague [1980] and Howard [1985].

orientation are similarly important to the volcanic hazard models [Smith et al., 1990; Connor et al., 1997]. Third, on a local scale the relationship between individual basaltic vents and faults is delineated, once again on the basis of detailed geologic field and magnetic data. Cumulatively, these data and the resulting models are the geologic basis for our estimate of the probability of volcanic eruptions through the proposed Yucca Mountain repository.

\section{Regional-Scale Structure: Crustal Structure and Its Influence on Magmatism}

Yucca Mountain is part of the western Great Basin, a region characterized by east-west extension and northwest trending dextral strike-slip or oblique strike-slip faults. Coupled with this overall pattern of crustal extension and transtension are numerous small-volume volcanic fields [Faulds and Varga, 1998].

Yucca Mountain lies within the eastern half of the Crater Flat basin, a half graben bounded on the west by the east dipping Bare Mountain fault (BMF) and by a series of west dipping antithetic faults that lie east of Yucca Mountain (Figure 1). The easternmost of these antithetic faults may be the Paintbrush-Stage Coach Road fault or, more likely, a buried fault defined by large gravity anomaly and referred to as the Gravity Fault [Winograd and Thordarson, 1975]. Yucca Mountain itself is a block of Miocene ignimbrite deposited unconformably on Paleozoic and Precambrian sedimentary and metasedimentary rocks. Faults within Yucca Mountain are predominantly north or northeast trending normal faults and northwest trending dextral oblique strike-slip faults that collectively compose a left-stepping en echelon fault array [Ferrill et al., 1999].

Interpretations of the tectonic setting of Yucca Mountain and Crater Flat have been controversial and varied [e.g., Maldonado, 1985; Hamilton, 1988; Carr, 1990; Scott, 1990; Snow and Prave, 1994; Faulds et al., 1994; Ferrill et al., 1996; Schweickert and Lahren, 1997; Fridrich, 1999; Fridrich et al., 1999]. One interpretation is that the BMF shallows with depth and forms a master detachment under the Crater Flat-Yucca Mountain half graben [Hamilton, 1988]. The west facing anti- thetic faults at and east of Yucca Mountain sole to a common detachment that intersects the BMF between 6 and $15 \mathrm{~km}$ depth (Figure 2). These antithetic faults accommodate rollover of the Crater Flat basin into the BMF. In this interpretation, Crater Flat formed either in response to simple east-west extension across the region or as a pull-apart in the releasing bend of a larger Walker Lane-style strike-slip system. Both of these interpretations are supported by, among other things, detailed balanced cross sections drawn across Crater Flat [Ferrill et al., 1996; Ofoegbu and Ferrill, 1998], evaluation of the paleomagnetic data from the basin [e.g., Rosenbaum et al., 1991; Hudson et al., 1994; Stamatakos and Ferrill, 1998] and nearby Bare Mountain [Stamatakos et al., 1998], Quaternary sedimentation patterns in Crater Flat basin [Stamatakos et al., 1997a], and a series of analog models designed to elucidate the evolution of extensional basins in pull-apart systems [Stamatakos and Ferrill, 1998; Rahe et al., 1997].

Extension across the basin since the Miocene produced a large-scale density contrast in the upper $5-6 \mathrm{~km}$ of the crust, with dense Precambrian and Paleozoic rocks of the BMF footwall juxtaposed with less dense tuffs and alluvium of the hanging wall (Figure 2). This fault delineates the west boundary of a north-south trending area of largely negative gravity anomalies (Plate 1a) that extend from Crater Flat south through the Amargosa Desert [e.g., Ponce and Oliver, 1995; Langenheim and Ponce, 1995] that are collectively termed the Amargosa Trough [O'Leary, 1996].

Regional geophysical data reveal that Pliocene-Quaternary volcanoes in the YMR are largely restricted to the Amargosa Trough (Plate 1a). Lathrop Wells cinder cone lies outside Crater Flat topographic basin but, on the basis of gravity data, is located within the larger north trending structural basin and at the margin of the prominent basement low in southernmost Crater Flat. Aeromagnetic anomalies [Langenheim, 1995; Langenheim et al., 1993] in the Amargosa Valley produced by buried Pliocene(?) basalts also lie within or at the margins of the southern extension of this basin. The most voluminous of these buried basalts lies close to a north trending gravity anomaly marking the eastern edge of Amargosa Valley alluvial basin in this area. Only Miocene basalt is mapped outside of the trough in the YMR (Plate 1a). One magnetic anomaly that is interpreted to be caused by buried basalt (anomaly B, Figure 
1b) may be the exception. This magnetic anomaly, discussed in more detail in section 3 , occurs $\sim 2 \mathrm{~km}$ west of the BMF.

An explanation for occurrence of Pliocene-Quaternary basalt in the Amargosa Trough is that the broad crustal density contrast created by the BMF is sufficient to initiate smallvolume decompression melting. Such decompression melting is favored in zones of enriched mantle lithosphere [Farmer et al., 1989; Leeman and Fitton, 1989; Lachenbruch and Morgan, 1990; Pedersen and Ro, 1992; Bergantz and Dawes, 1994; Hawkesworth et al., 1995], like the YMR, that have previously been enriched in incompatible elements, enabling melt formation at lower temperatures than is possible in normal or depleted mantle [McKenzie and Bickle, 1988; Yogodzinski and Smith, 1995]. Based on mineralogical phase relationships and geochemical studies, decompression-induced partial melting of enriched lithospheric mantle likely occurs at depths between 40 and $80 \mathrm{~km}$ in the western Great Basin [Takahashi and Kushiro, 1983; Rogers et al., 1995]. In stark contrast to the depth of melt generation, crustal extension most strongly influences the upper brittle crust $(<15 \mathrm{~km}$ depth) by producing large density variations across faults. Thus the direct link between crustal extension and magmatism relies on the possibility that density variations in the crust produced during extension are sufficient to initiate decompression melting at much greater depths within the mantle.

The average density difference between a $5.6 \mathrm{~km}$ column of rock beneath Crater Flat and one beneath Bare Mountain is $280 \mathrm{~kg} / \mathrm{m}^{3}$, calculated from the cross section using average rock densities for the region (Figure 2) [McKague, 1980; Howard, 1985]. Beneath $5.6 \mathrm{~km}$, large density differences are not expected because faulting at those levels juxtaposes rocks of similar densities. Given that the lithostatic pressure at a geographic location $x, y$ and depth $Z$ is

$$
P_{L}(x, y, Z)=\int_{0}^{Z} \rho(z) g d z
$$

where is $g$ is gravity $\left(9.8 \mathrm{~m} / \mathrm{s}^{2}\right)$ and $\rho(z)$ is rock density at depth $z$ (estimated from the cross section), the lateral change in lithostatic pressure across the BMF at $Z=5.6 \mathrm{~km}$ is $\sim 15$ $\mathrm{MPa}$.

Following the methods of Gupta and Grant [1984], the Bouguer gravity data were used to infer lateral changes in apparent density, $\Delta \rho(x, y)$, in the shallow crust across the entire YMR (Plate $1 \mathrm{~b}$ ), assuming that $\Delta \rho(z)$ is constant between the surface and $Z$. The change in lithostatic pressure below depth $Z$ of the map region is

$$
\Delta P_{L}(x, y, Z)=\Delta \rho(x, y) g Z,
$$

for $Z=5-6 \mathrm{~km}$ and $\Delta \rho(x, y)=230-280 \mathrm{~kg} / \mathrm{m}^{3}$ across the BMF in southern Crater Flat, yielding $\Delta P_{\ell}(x, y, Z)=11-16$ $\mathrm{MPa}$, in good agreement with density contrasts obtained from the balanced cross section. The apparent density map (Plate 1b) also reveals that this density contrast persists north and south of Bare Mountain, making it a regional (i.e., longwavelength) feature. Apparent density values remain low east of the $\mathrm{BMF}$ for at least $50 \mathrm{~km}$ and remain high west of the $\mathrm{BMF}$ to the edge of the gravity map, $20 \mathrm{~km}$ from the fault (Plate 1b).

Recognition of long-wavelength density variation is important because only long-wavelength crustal density variations can produce meaningful pressure variations in the mantle [e.g.,
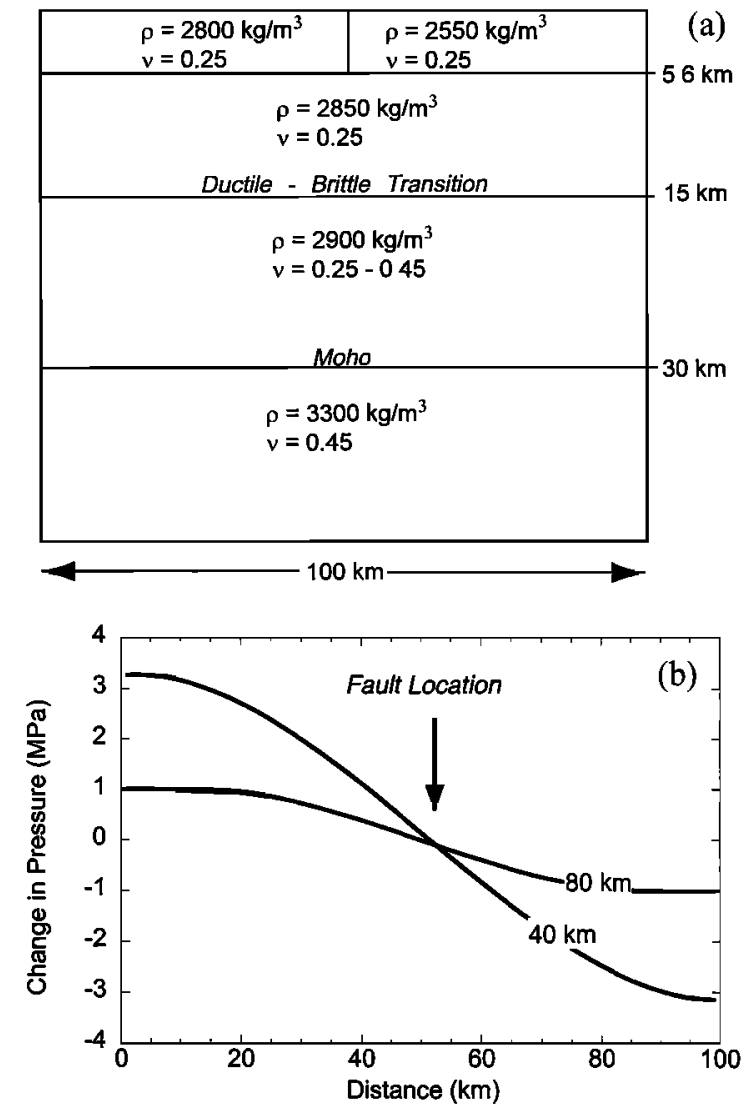

Figure 3. (a) A simple finite element model of pressure variation in the lithosphere was constructed using the generalized cross section from Wernicke [1992] and including a large density variation in the upper $5.6 \mathrm{~km}$ of the crust. The bulk densities $\rho$ and values of Poisson's ratio $\nu$ are indicated. (b) Pressure changes of $7 \mathrm{MPa}$ and $2 \mathrm{MPa}$ are expected at 40 and 80 $\mathrm{km}$ depth, respectively, on the basis of this model.

Anderson, 1989]. In contrast, the affects of local density variations, such as those produced by topography, attenuate rapidly with depth. An estimate of $\Delta P_{L}(x, y, Z)$ at $Z=40-100 \mathrm{~km}$, given the density contrast across the BMF, was made using a linear-elastic finite element model and simplified geometry. Key elements of the model include the following: a vertical step producing the density contrast from $Z=0-5.6 \mathrm{~km}$; increase in density and Poisson's ratio with depth; zerodisplacement conditions at the west, east, and basal boundaries of the model space; and a free surface (zero stress) at the top of the model space (Figure 3a). In addition to the lateral density contrast at $<5.6 \mathrm{~km}$, vertical layering in the model includes the brittle-ductile transition at $15 \mathrm{~km}$ and a flat-lying Moho discontinuity at $30 \mathrm{~km}$ [Wernicke, 1992]. Under gravitational loading, this model produces lateral pressure variations of the order of $7 \mathrm{MPa}$ at $40 \mathrm{~km}$ depth (Figure 3b), which further attenuate to $2 \mathrm{MPa}$ at $80 \mathrm{~km}$ and $<1 \mathrm{MPa}$ at $100 \mathrm{~km}$. Changing the Poisson's ratio between 0.25 and 0.45 for the depth interval $15-30 \mathrm{~km}$ did not significantly change these pressures $(<1 \mathrm{MPa})$.

Mantle rocks at depths of $40-100 \mathrm{~km}$ are under average lithostatic pressures of 1-3 GPa. A change of 2-7 MPa across the density discontinuity thus represents a very small fraction of the total pressure at likely depths of mantle partial melting. Solidi for anhydrous peridotites appear relatively isothermal at 
(a)

(b)
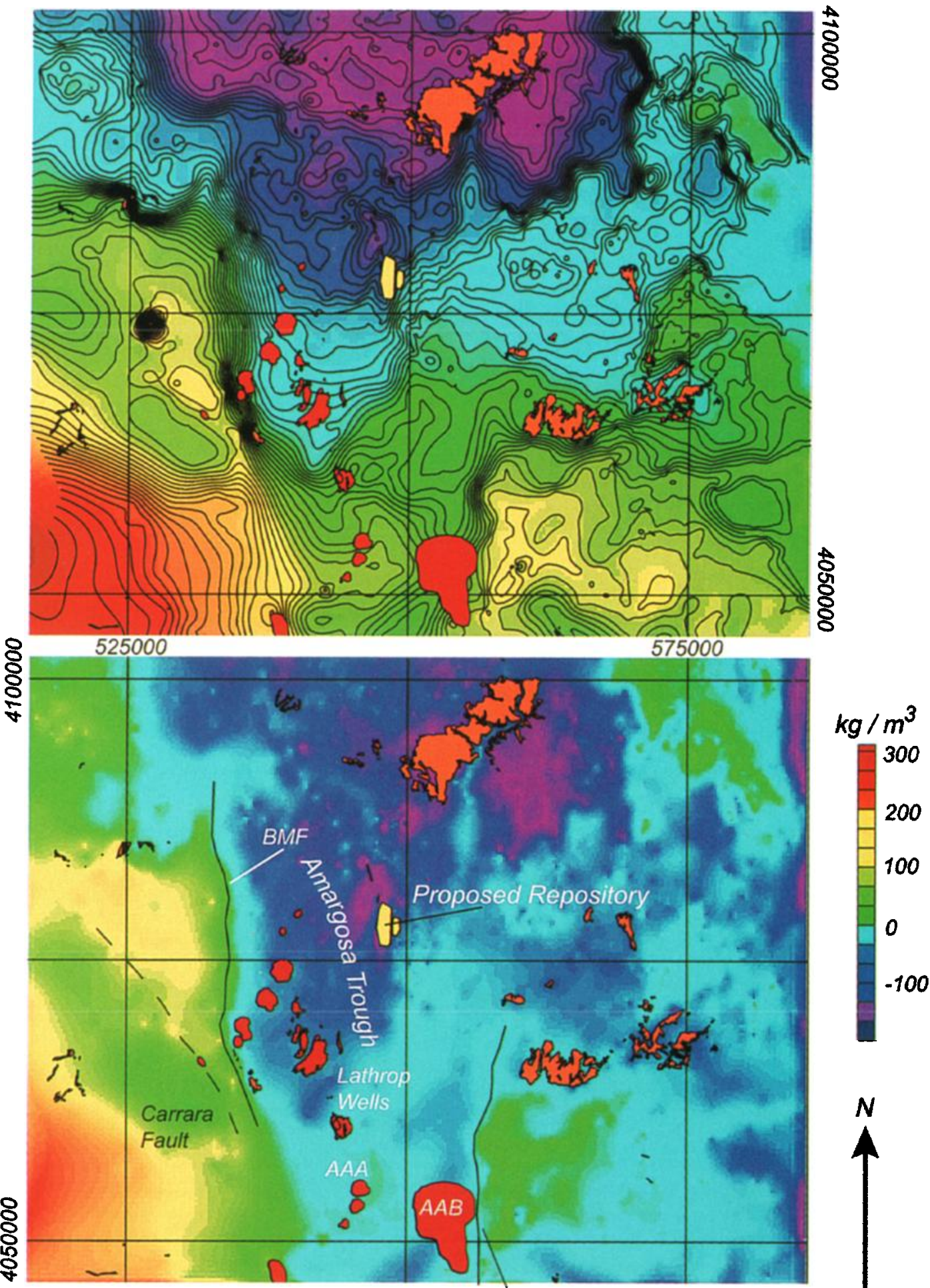

Gravity Fault

\section{$25 \mathrm{~km}$}

Plate 1. (a) Approximately 8400 gravity stations are used to create this complete Bouguer anomaly map of the YMR. Contour interval is $2 \mathrm{mGal}$. Miocene basalt (orange) and Pliocene-Quaternary basalt (red) are from Frizzell and Schulters [1990]. Magnetic anomalies (red) are from Langenheim et al. [1993] and this study. Data were compiled from numerous sources and obtained from the Geophysics Data Repository at LawrenceBerkeley Laboratory. See Ponce and Oliver [1995]. (b) Change in mean apparent density $\left(\mathrm{kg} / \mathrm{m}^{3}\right)$ derived from gravity data is shown. 


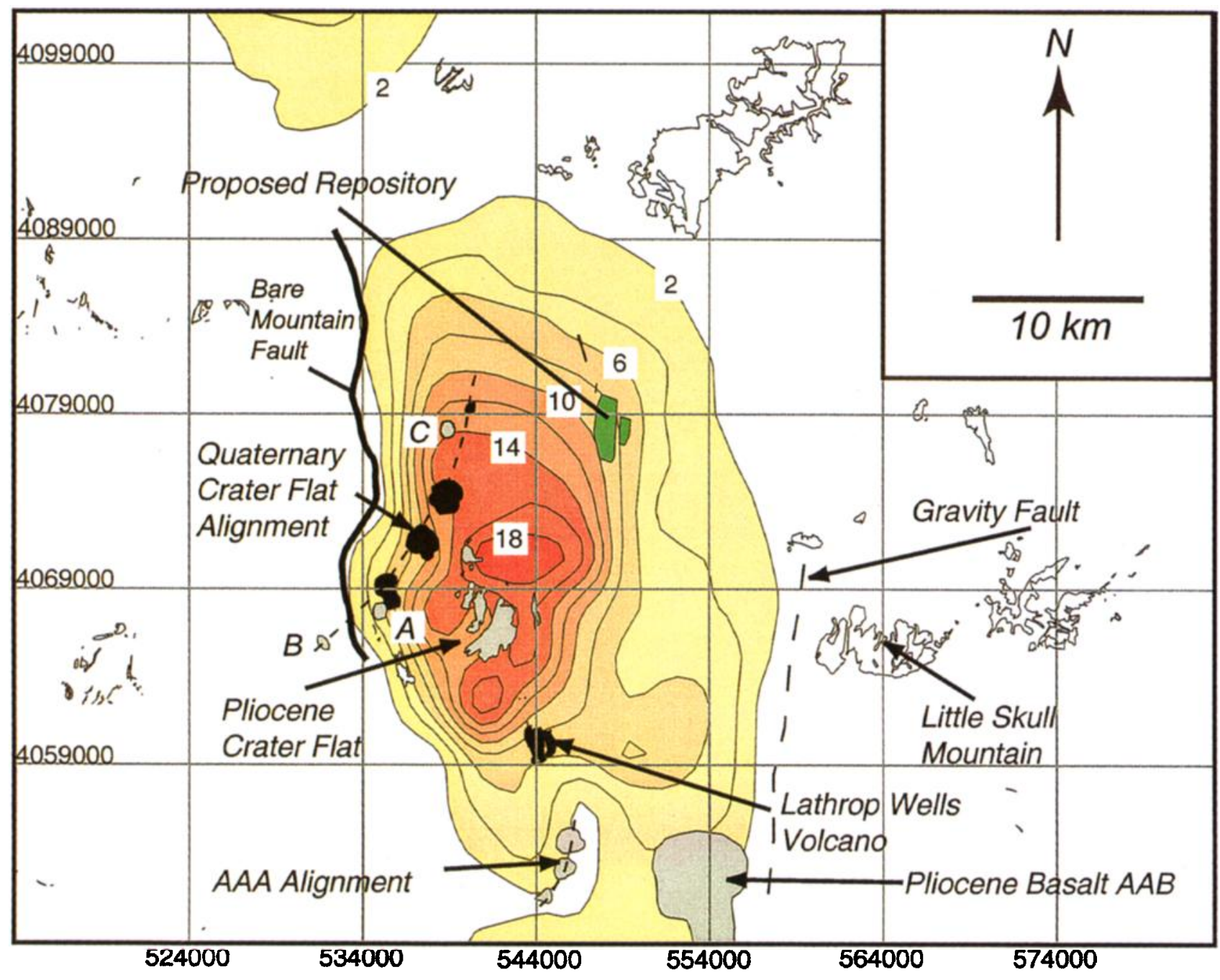

Plate 2. The spatial recurrence rate (volcanic events $/ \mathrm{km}^{2}$ ) contoured for the YMR, based on the distribution of Quaternary volcanism and its relationship to the BMF (see appendix). The contour interval is $2 \times 10^{-4}$ volcanic events $/ \mathrm{km}^{2}$.

1-3 GPa pressures [e.g., Jaques and Green, 1980]. Small pressure changes of 2-7 MPa would be unlikely to induce partial melting unless these peridotites were at the solidus. In contrast, solidi for volatile-bearing peridotites appear relatively more sensitive to small variations in pressure than anhydrous peridotites [Mysen and Boettcher, 1975; Eggler, 1978; Green et al., 1987; Harry and Leeman, 1995]. Some <5 Ma basalts of the YMR contain phenocrysts of pargasitic amphibole, and most have geochemical characteristics consistent with phlogopite or amphibole as a residual or fractionating mineral phase [Vaniman et al., 1982]. These features indicate partial melting that occurred under hydrous conditions. Isotopic data also are consistent with a source for YMR basalt in metasomatized lithospheric mantle [Farmer et al., 1989; Yogodzinski and Smith, 1995]. Provided the metasomatized peridotites are very near the solidus, 2-7 MPa variations in pressure may be sufficient to induce small-volume partial melts by isothermal decompression.

Basaltic volcanism within the Amargosa Trough thus can be explained by the juxtaposition of crustal extension associated with the BMF onto a more regionally extensive zone of metasomatized mantle lithosphere. Although this zone of metasomatized mantle may extend for at least $50 \mathrm{~km}$ away from the Amargosa Trough [e.g., Yogodzinski and Smith, 1995], compo- sitionally similar basalt is concentrated in areas of relatively large-scale crustal extension, such as the Funeral Formation of the Greenwater range [Asmerom et al., 1994]. With these observations (Figure 2 and Plate 1a) and model in mind, the apparent density map was normalized to be a probability density function that effectively weights the expected distribution of future volcanic eruptions in favor of areas east of the BMF. This information, together with vent cluster models [Connor and Hill, 1995; Condit and Connor, 1996; Conway et al., 1998] (see appendix, equations (A7)-(A9)), is used to estimate the expected location of basaltic vents and vent alignments in the YMR (Plate 2).

\section{Subregional Scale: \\ Volcano Alignments and Faults}

Within the Amargosa Trough, stress orientation, strain rate, and fault distribution influence the development of vent alignments. Issues related to vent alignments that arise in hazard assessment include their likelihood to develop, orientation, length [Nakamura, 1977; Zoback, 1989; Connor, 1990; Smith et al., 1990], and potential to reactivate after comparatively long periods of quiescence [Conway et al., 1997]. 


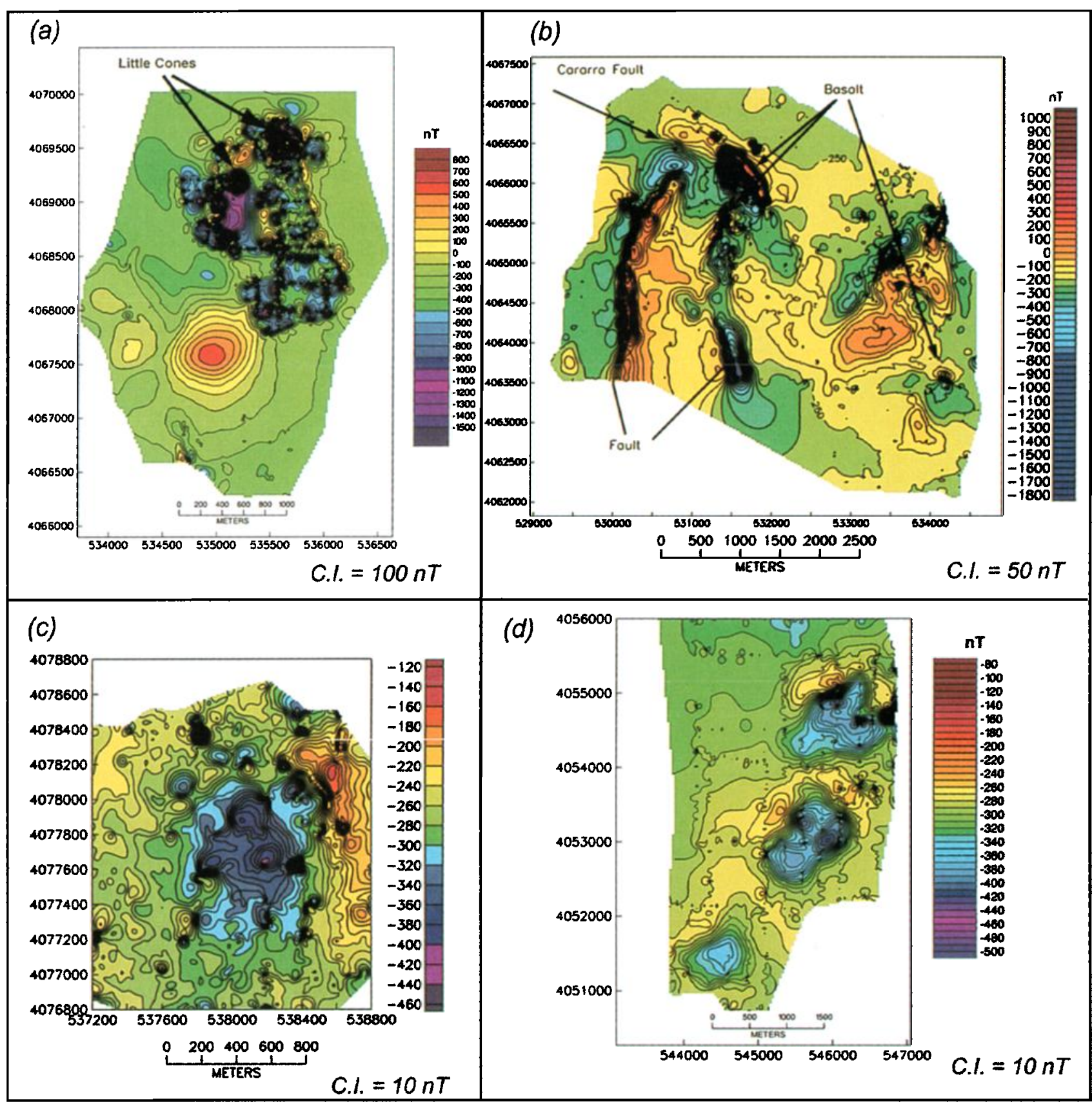

Plate 3. Ground magnetic anomaly maps of (a) southern Crater Flat, including the Little Cones (labeled A in Figure 1), (b) Carrara fault area, south of Crater Flat and labeled B on Figure 1), (c) southwest of Northern Cone (labeled $\mathrm{C}$ on Figure 1), and (d) a buried vent alignment (labelled AAA in Figure 1). All map coordinates are universal transverse Mercator (UTM) (North American Datum (NAD) 83), and contour interval $(\mathrm{CI})$ varies as indicated.

The most prominent vent alignment in the YMR is the arcuate NE trending Quaternary Crater Flat alignment, consisting of five cinder cones aligned southwest of Northern Cone (Figure 1b) [Champion, 1991; Faulds et al., 1994; Bradshaw and Smith, 1994]. Three magnetic anomalies are mapped along the alignment that reveal the presence of older, buried basaltic lavas (A, B, and C in Figure 1b). A normal magnetic anomaly $\sim 2 \mathrm{~km}$ south of the Little Cones (labeled $A$ in Figure 1b), the southernmost cones in the Quaternary Crater Flat alignment, has a peak-to-peak amplitude of $1100 \mathrm{nT}$ and separation of 750 m (Plate 3a) [Langenheim, 1995; Connor et al., 1997; Sta- matakos et al., 1997a]. This anomaly was successfully modeled as a thin, roughly circular lava flow buried at a depth of $\sim 150 \mathrm{~m}$.

A second magnetic anomaly on the trend of the Quaternary Crater Flat alignment (labeled B in Figure 1b), termed the Carrara fault basalt [Stamatakos et al., 1997b], consists of reversely magnetized rocks with very high remanent magnetizations. This anomaly is located at the intersection of the Carrara fault and north trending faults (Plate 3b), placing the Carrara basalt $\sim 2 \mathrm{~km}$ west of the BMF, just outside the Amargosa Trough. The excursion of basalt west of the BMF may be related to distributed faulting near the intersection of the Car- 
rara fault and BMF. Alternatively, the Carrara fault basalt may be Miocene in age and less affected during its ascent and eruption by the BMF than younger basalts.

A third prominent magnetic anomaly is $2.5 \mathrm{~km}$ southwest of Northern Cone [Magsino et al., 1998] (labeled C in Figure 1b). This is the lowest amplitude of the three magnetic anomalies mapped on the Quaternary Crater Flat alignment. A striking feature of this anomaly is that it appears to be rotated clockwise, based on the relationship between its positive and negative peaks (Plate $3 \mathrm{c}$ ). This rotation of the anomaly is consistent with tectonic rotations in the area and suggests that this basalt is likely older than basalts that crop out along the alignment. Cumulatively, the geology and geophysical mapping indicate that the Quaternary Crater Flat alignment is up to $16 \mathrm{~km}$ in length and may have been reactivated through time.

Our magnetic surveys of anomaly AAA (Figure $1 b$ ) provide further evidence of NE trending alignments. This map delineates three separate anomalies associated with shallowly buried, reversely magnetized rock (Plate $3 \mathrm{~d}$ ). These anomalies are distributed over $4.5 \mathrm{~km}$ on a NE trend. Each anomaly has a $70-150 \mathrm{nT}$ amplitude and a shape typical for basaltic vents. On the basis of these data, we interpret anomaly AAA as three basalt vents that form a short alignment.

Other vent alignments in the region include the $\sim 0.3 \mathrm{Ma}$ Sleeping Buttes alignment, consisting of two cinder cones aligned on a NE trend, $40 \mathrm{~km}$ northwest of Yucca Mountain, and the Pliocene Crater Flat vents (Figure 1b), which form a north trending alignment of $6-8$ vents, erupted $\sim 3.8 \mathrm{Ma}$ [Fleck et al., 1996]. In sum, five vent alignments, comprising a total of 18 vents, have formed or reactivated in the PlioceneQuaternary. The remaining six Pliocene-Quaternary vents are not members of alignments. Of these six, four are known only from magnetic mapping and, in one case (anomaly AAB), drilling. There may be multiple vents associated with some of these anomalies that have not been resolved by aeromagnetic surveys.

Future volcanic activity may produce similar alignments. Given the vent alignment data, a probability density function for the length of new alignments is

$$
f_{L}(l)=\left\{\begin{array}{cl}
U\left[l_{\mathrm{min}}^{1 / 2}, l_{\mathrm{mux}}\right] & l=0 \\
\frac{2}{2} & l>0
\end{array},\right.
$$

where $l_{\min }$ and $l_{\text {max }}$ are the minimum and maximum halflength of an alignment centered at a geographic location $x, y$ and $U$ is the uniform random probability distribution, bounded by $l_{\min }$ and $l_{\max }$. By this definition, $50 \%$ of future YMR basaltic eruptions will not create alignments and will only disrupt the repository if they fall within the site boundary. The remaining $50 \%$ form alignments that affect areas up to a distance $l_{\max }$ from the point $x, y$. The value of $l_{\max }$ can be chosen as 5.5-8 $\mathrm{km}$, taking the Quaternary Crater Flat alignment as the maximum alignment half-length. Given observations in other volcanic fields [Connor, 1990; Lutz and Gutmann, 1995; Connor et al., 1992], $l_{\max }$ may be $10 \mathrm{~km}$ or more.

A distribution function for alignment azimuth, $f_{\Phi}(\varphi)$, is better constrained by the data on vent alignments, regional stress distribution and the orientations of high-dilation tendency faults. The three youngest YMR alignments trend $20^{\circ}-$ $30^{\circ}$, parallel to the maximum principle horizontal compressional stress in the region, $\sim 28^{\circ}$ [e.g., Morris et al., 1996]. Under these circumstances,

$$
f_{\Phi}(\varphi)=U\left[20^{\circ}, 35^{\circ}\right]
$$

The probability distributions $f_{L}(l)$ and $f_{\Phi}(\varphi)$ are included in the estimate of volcanic disruption of the repository (see appendix).

\section{Local Scale: Positions of Individual Vents}

Faults may also control the locations of vents on local scales regardless of whether vent alignments develop or not (Figures $4 a-4 c$ ) [Settle, 1979]. For example, a normal fault crossed by a strike-slip fault will tend to dilate more at the fault intersection, creating additional space for the intrusion of ascending magma (Figure 4a). There is ample evidence of such localization of cinder cones along faults in the YMR. Langenheim et al. [1993] noted that anomaly AAB occurs at the intersection of the north trending gravity fault and the Rock Valley Fault in the Amargosa Desert. Lathrop Wells volcano is located along the trend of the Stage Coach fault, south of Yucca Mountain at the intersection with several north trending faults (Figure 1a). The Carrara fault basalt (Plate 3d) is located at the intersection of north trending normal and NW trending strike-slip faults.

Ascending a steeply dipping fault, magmas may be laterally diverted by as much as $5 \mathrm{~km}$, depending on the depth of dike capture by the fault and the dip of the fault plane [McDuffie et al., 1994] (Figures 4c and 5a-5f). Dikes will also have a tendency to break out of the fault system and propagate vertically at shallow depth because of rapid variations in the magnitude and orientation of the stress field (free surface effects). Given these free surface effects, it is not surprising that cinder cones are often located adjacent to faults in the hanging wall. Consequently, the total amount of lateral diversion will depend on the depth at which the dike begins following the fault and the dip of the fault. In part, the arcuate map pattern of the Quaternary Crater Flat alignment (Figure 1a) may owe its origin to such a mechanism. The dip of the BMF shallows progressively northward [Ferrill et al., 1996], and cinder cones along the alignment are displaced progressively eastward, consistent with the geometry illustrated in Figures $4 \mathrm{~b}$ and $5 \mathrm{~d}$.

Basin and Range normal faults commonly grow by formation, propagation, and amalgamation of smaller normal faults [Ferrill et al., 1999]. Such progressive fault growth commonly involves development of en echelon fault systems with individual normal fault segments separated by relay ramps. Ferrill et al. [1999] identified the Solitario Canyon fault and related west dipping faults on the western edge of Yucca Mountain as one such set of left-stepping en echelon faults produced by progressive deformation. The Pliocene vents immediately south and west of these fault segments mimic this trend, forming a left-stepping array of vent alignments. Thus en echelon fault geometries may provide preferential pathways to the surface for ascending magmas along individual fault segments (Figure 4b). Linear, north trending magnetic anomalies intersect Northern Cone, located in Crater Flat $\sim 8 \mathrm{~km}$ from the repository site [Connor et al., 1997]. These anomalies result from vertical offsets in ignimbrite across faults that are arguably part of the same array of left-stepping normal faults. Bounding the western edge of the proposed repository, a $11.7 \pm 0.3$ Ma dike [Smith et al., 1997] intruded a north trending segment of the Solitario Canyon fault. Such relationships indicate that the en echelon array of faults has hosted dikes at least three times in the Miocene-Quaternary. 


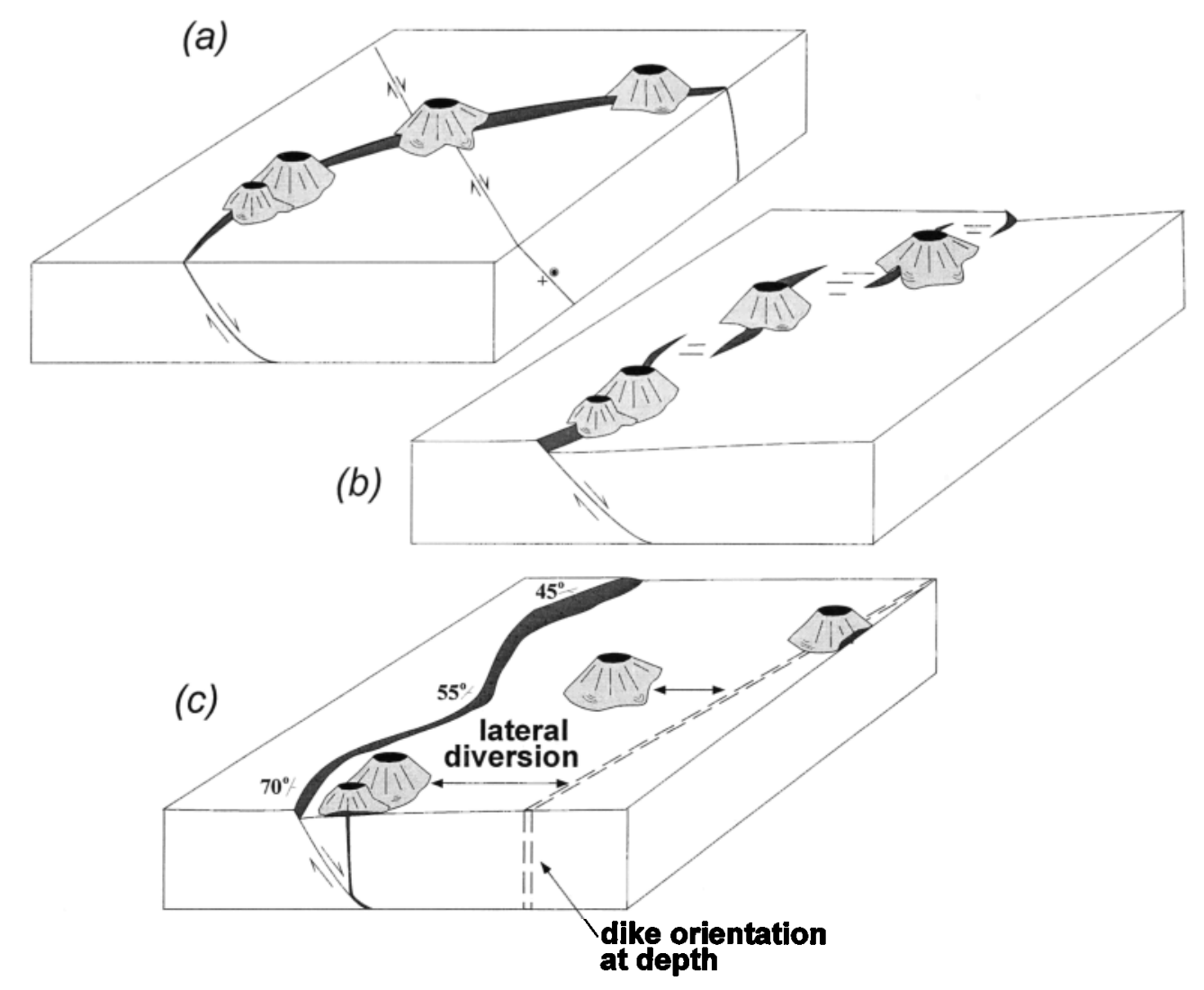

Figure 4. Control of vent distributions on local scales by faults, due to variation in fault geometries. (a) Vents may be preferentially emplaced at the intersections of faults. (b) Increasing displacement of normal faults in the Basin and Range can produce en echelon fault segments. Vents tend to form along these fault segments. (c) Faults may capture and redirect ascending dikes if fault planes are low-energy pathways to the surface, resulting in lateral diversion of dikes and cinder cones from the position of the dike at depth. Dikes will break out of the fault plane near the surface and be displaced from the fault trace as a function of fault dip.

\section{Probability Estimates}

Probability models rely on estimates of the expected regional recurrence rate of volcanism in order to calculate the probability of future volcanic activity. These estimates vary between 2 and 12 volcanic events per million years (v/Myr) [e.g., Ho, 1991, 1992; Ho et al., 1991; Crowe et al., 1992; Connor and Hill, 1993], with various definitions of a volcanic event accounting for at least part of this range. In addition to this regional recurrence rate, the probability model accounts for the expected spatial distribution of future basaltic volcanism. Estimate of this spatial distribution can integrate independent geologic data to varying degrees. This, in turn, changes the probability estimate for volcanic disruption of the proposed repository. In the following, progressively more geologic information is incorporated into the analysis to demonstrate the sensitivity of probability estimates to these data and models.

In the simplest model the future distribution of volcanoes depends solely on where volcanoes have erupted in the past. Treating all Pliocene-Quaternary vents as individual volcanic events, the mean distance to nearest-neighbor volcanic event is $3.8 \mathrm{~km}$ with a standard deviation of $5.8 \mathrm{~km}$. Some vents such as SW and NE Little Cones are quite closely spaced and have been treated as single volcanic events in some hazard analyses [Crowe et al., 1992; Connor and Hill, 1995]. Treating vents spaced more closely than $1 \mathrm{~km}$ as single volcanic events, the mean distance to nearest-neighbor volcanic event increases to
$5.0 \mathrm{~km}$, and the standard deviation increases to $5.9 \mathrm{~km}$. Alternatively, defining volcanic events as vents and vent alignments gives a mean distance to nearest-neighbor volcanic event increase to $7.0 \mathrm{~km}$, with a standard deviation of $6.4 \mathrm{~km}$. Distance to nearest-neighbor volcanic event is shown cumulatively for each of these three definitions in Figure 6. The observed cumulative nearest-neighbor distance distribution functions are compared to expected distribution of vents calculated with a Gaussian kernel (see appendix) and smoothing parameter $h=$ 3-9 km.

Comparison of expected and observed distribution leads to a natural definition of conservatism for a site-specific hazard analysis. For example, the distance between the proposed repository and its nearest-neighbor Quaternary volcano is 8.2 $\mathrm{km}$. Gaussian kernel functions for the expected distribution of vents with $h=7-9 \mathrm{~km}$ are conservative because a greater fraction of volcanic events occur at nearest-neighbor distances $<8.2 \mathrm{~km}$ than predicted by the model, whereas a Gaussian kernel function with $h=3 \mathrm{~km}$ is not conservative (Figure 6). In other words, probability models using $h=7-9 \mathrm{~km}$ are not likely to underestimate hazard for the YMR vent distribution. An $h=5 \mathrm{~km}$ smoothing parameter is conservative for probability models based on individual vent distributions, but not for a model based on vent alignment distributions. Only considering the distribution of past (Pliocene-Quaternary) volcanism, the annual probability of volcanic eruptions within the 

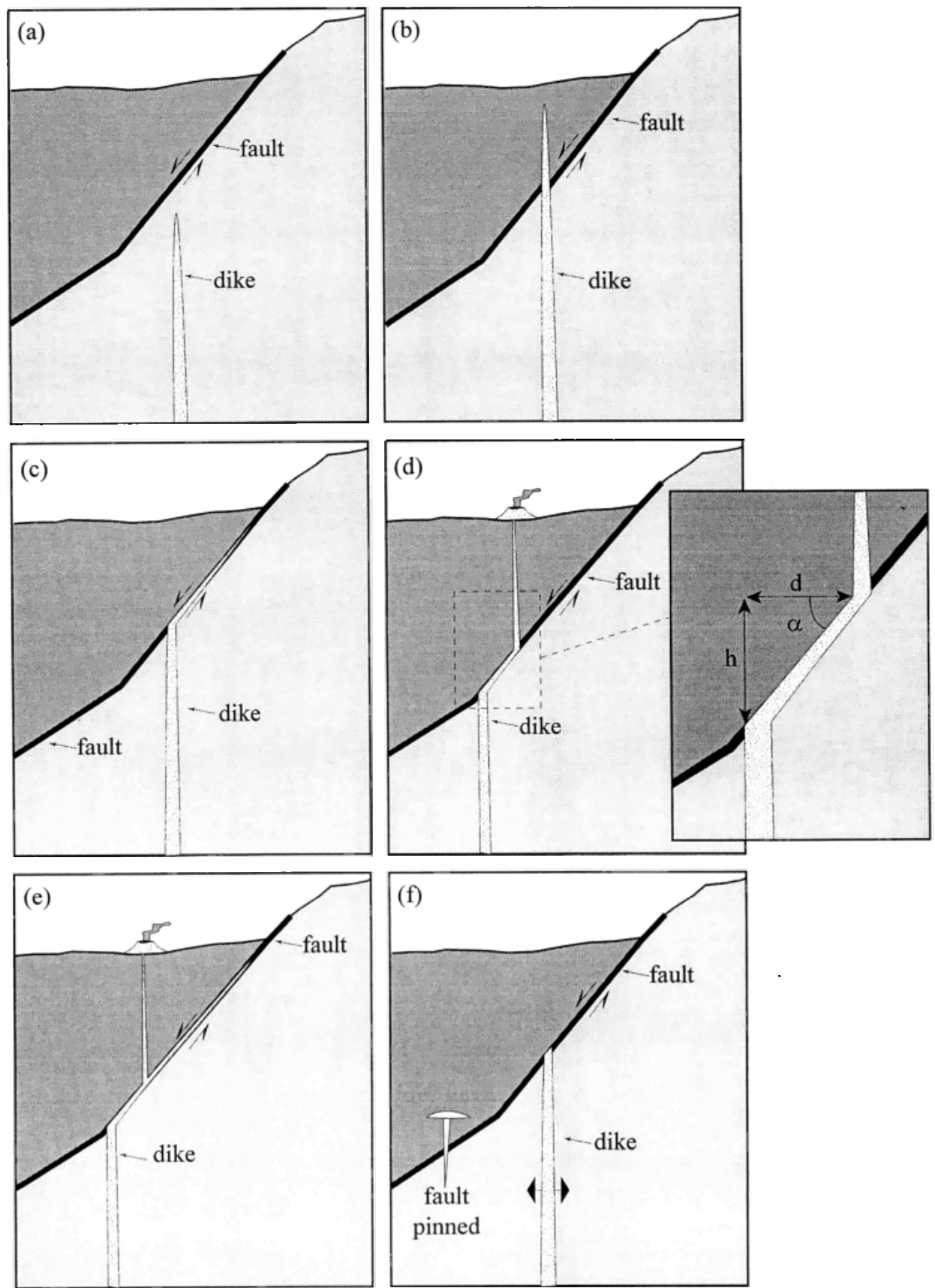

Figure 5. Schematic models of fault dike interaction. Ascending magma is shown by stippled pattern, and fault is shown by thick solid lines. (a) There are several possible modes of interaction between a vertically propagating dike and a planar weakness, such as a fault. (b) The dike may propagate vertically through the fault plane if less energy is required to fracture rock vertically than dilate the dipping fault plane. (c) The dike will intrude the fault plane and use it as a conduit if the fault plane represents the low-energy pathway to the surface. (d) Near the ground surface, stress changes rapidly due to free surface affects causing the dike to break out of the fault zone. The lateral offset between the original position of the dike and the position of the cinder cone $d$ depends on the dip of the fault $\alpha$ and depth of dike-fault intersection relative to the depth of breakout $h$. Dikes may also (e) bifurcate upon intersecting the fault or (f) terminate at the fault, accommodating strain by dike widening below the fault and fault slip above.

repository boundary is between $0.5 \times 10^{-8}$ and $3.5 \times 10^{-8}$ (Figure 7).

Additional geologic information is included in the analysis through the probability density functions of alignment length, $f_{L}(l)$, and orientation, $f_{\mathrm{\Phi}}(\varphi)$. Annual probabilities of volcanic eruptions within the repository boundary were calculated using $l_{\min }=100 \mathrm{~m}, 5200 \mathrm{~m} \leq l_{\max } \leq 10,200 \mathrm{~m}, 20^{\circ}<\varphi<35^{\circ}$, and $5 \mathrm{~km} \leq h \leq 7 \mathrm{~km}$. In this case, the locations (geographic centers) of only three Quaternary volcanic events, Lathrop Wells, Quaternary Crater Flat, and the Sleeping Butte alignment, were used to calculate the expected vent distribution using a Gaussian kernel. Assuming a regional recurrence rate 


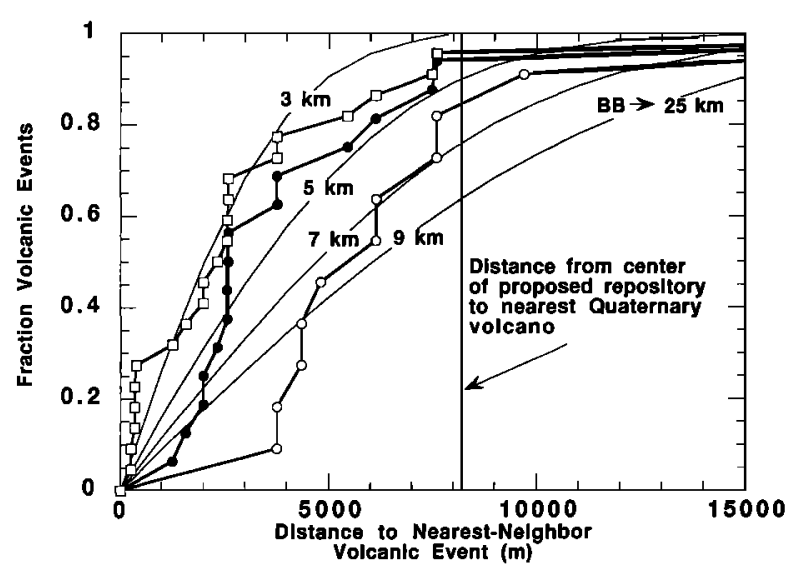

Figure 6. Comparison of observed fraction of PlioceneQuaternary volcanoes within a given distance of their nearestneighbor volcano with Gaussian kernel and smoothing parameter $h=3,5$, and $7 \mathrm{~km}$. Observed curves include all vents (open squares), all vents or vent pairs more closely spaced then $1 \mathrm{~km}$ (solid circles), and vents and vent alignments (open circles). Buckboard Mesa (BB) is an outlier in the distribution as it is $\sim 25 \mathrm{~km}$ from its nearest neighbor. The center of the repository site is located $8.2 \mathrm{~km}$ from Northern Cone, the nearest Quaternary volcano (see Figure $1 \mathrm{~b}$ for vent locations).

of $3 \mathrm{v} / \mathrm{Myr}$ yields annual probabilities of volcanic eruptions within the repository boundary between $1 \times 10^{-8}$ and $3 \times$ $10^{-8}$. Thus accounting for the increased area potentially affected by the formation of vent alignments is more or less offset by the decrease in total number of expected events, reflected in the lower recurrence rate.

Annual probability of volcanic eruptions within the repository boundary are next calculated weighting the expected vent distribution using the apparent crustal density map. This greatly reduces the probability of future basaltic eruptions west of the BMF and increases probability east of the BMF. Using the same parameters as previously, probabilities of volcanic eruptions within the repository boundary are $3-5.5 \times 10^{-8}$,

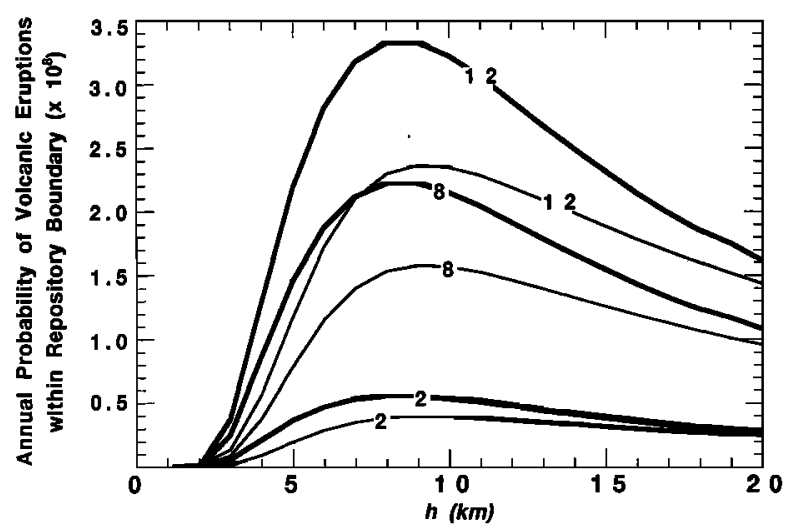

Figure 7. Annual probability of volcanic eruptions within the repository boundary. A Gaussian kernel is used with smoothing parameter $h$, varying from 0 to $20 \mathrm{~km}$ (see appendix). Curves are shown for various regional recurrence rates of volcanic vent formation $\left(2 \times 10^{-6} \mathrm{v} / \mathrm{yr}, 8 \times 10^{-6} \mathrm{v} / \mathrm{yr}\right.$, and $12 \times$ $10^{-6} \mathrm{v} / \mathrm{yr}$, where $\mathrm{v}$ is volcanic events), based on the distribution of Quaternary volcanoes (thick curves) and PlioceneQuaternary volcanoes (thin curves).

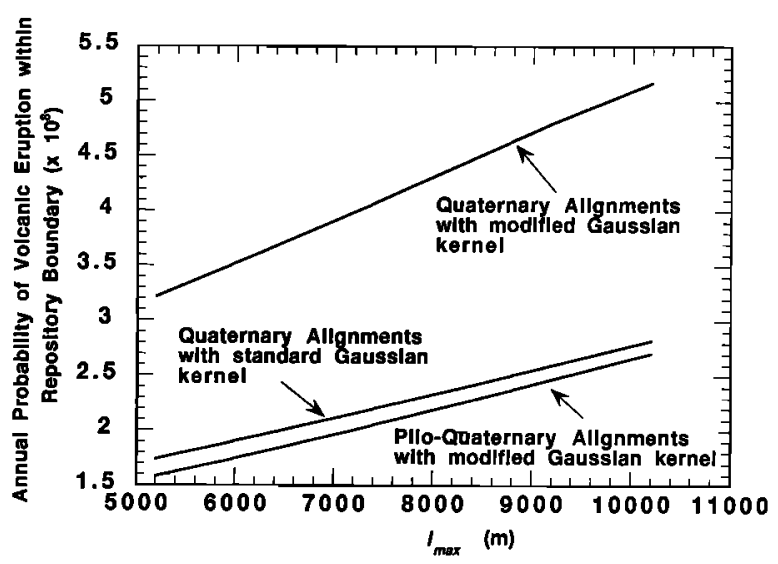

Figure 8. Annual probability of volcanic eruptions within the repository boundary as a function of maximum vent alignment half-length $l_{\max }$. Probabilities are calculated using a regional recurrence rate of $3 \times 10^{-6} / \mathrm{yr}$. The three separate curves show probability estimates that do not incorporate regional structure (standard Gaussian kernel) and that do incorporate regional structure (modified Gaussian kernel), based on the distribution of Quaternary volcanism and Pliocene-Quaternary volcanism.

assuming a regional recurrence rate of $3 \mathrm{v} / \mathrm{Myr}$ (Figure 8 ). This range of probability estimates is roughly double those that do not consider crustal structure. Including Pliocene volcanoes in the estimate of the kernel function decreases the annual probability to $1.5-3 \times 10^{-8}$, because many Pliocene volcanoes are comparatively far from the repository. Varying regional recurrence rate of volcanic events (including alignment formation) between 1 and $5 \mathrm{v} / \mathrm{Myr}$, annual probability of volcanic eruptions within the repository is between $1 \times 10^{-8}$ and $9 \times 10^{-8}$ (Figure 9).

\section{Discussion}

The geological and geophysical evidence suggests that neotectonic setting influences patterns of basaltic volcanic activity on a number of scales. In their analysis of vent distribution in the YMR, Connor and Hill [1995] identified three major features that affect probabilistic volcanic hazard estimates: shifts in the locus of basaltic volcanism over long time periods, vent

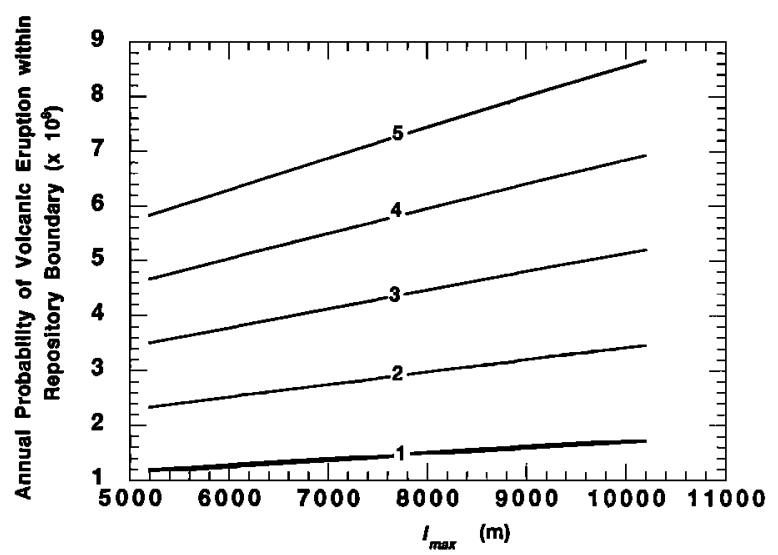

Figure 9. Annual probability of volcanic eruptions within the repository boundary using regional recurrence rates of $1 \times$ $10^{-6} / \mathrm{yr}$ to $5 \times 10^{-6} / \mathrm{yr}$. 
clustering, and vent alignment formation. Each of these features of vent distribution can be revisited in light of the structural and neotectonic setting of the volcanic field outlined in sections 2-4.

\subsection{Shifts in the Location of Basaltic Volcanism}

Crowe and Perry [1989] suggested that volcanism has shifted from east to west over time in the YMR. An important aspect of this shift of the locus of magmatism is that it was accompanied by a change in the petrogenesis of YMR basalts. Miocene Basin and Range basalts generally were produced by higher degrees of partial melting and have a greater asthenospheric component than Plio-Quaternary basalts [Farmer et al., 1989]. Pliocene-Quaternary basalts tend to be lithophile-enriched and are more clearly related to decompression melting in the lithosphere. Furthermore, voluminous Miocene basalts are present in all areas in the YMR where Plio-Quaternary basalts erupted. Thus, rather than a large-scale regional shift in volcanic activity of the type identified in other volcanic fields [e.g., Foland and Bergman, 1992; Tanaka et al., 1986; Condit and Connor, 1996], the focusing of basaltic magmatism in Crater Flat and the Amargosa Desert since the Pliocene may simply reflect a transition to dominantly decompression melting of enriched lithosphere [Yogodzinski and Smith, 1995].

\subsection{Vent Clustering}

Crowe et al. [1992] and Sheridan [1992] noted that basaltic vents appear to cluster in the YMR. Connor and Hill [1995] analyzed volcano clustering in the region and reached three conclusions. First, vents form statistically significant clusters in the YMR. Spatially, volcanoes <5 Ma form four clusters. The Crater Flat and Amargosa Valley clusters overlap somewhat because of the position of Lathrop Wells volcano and the three anomaly AAA vents. The Sleeping Butte Quaternary volcanoes and the Thirsty Mesa basalts form a third cluster; the Buckboard Mesa vents form the fourth cluster. Second, a volcanic event located at the repository would be spatially part of, albeit near the edge of, the Crater Flat cluster, rather than forming between or far from clusters in the YMR. Third, three of the four clusters contain Miocene-Quaternary basalt, indicating that these clusters are long-lived and provide some indication of the likely areas of future volcanism.

Based on a model of magma generation in response to extension, recurring Quaternary volcanism within YMR vent clusters occurs because of the combination of two conditions that together give rise to small-volume melts: (1) mantle rocks beneath these regions are very near their solidus, perhaps over large regions compared to the area of vent clusters, and (2) mantle rocks in these areas experience a small volumetric strain in response to extension of the crust across the BMF, sufficient to produce melts. A given rate of extension will produce the greatest volumetric strain rate directly beneath the lateral change in density in the crust, such as at the BMF. Thus, with continuing extension, mantle in the region of this inflection has the greatest opportunity of producing partial melts from a given amount of crustal extension. Therefore episodes of extension and basaltic volcanism may correlate temporally as well, because pressure variations in the mantle will likely equilibrate because of ductile flow over time. In other words, pressure changes in the mantle which result from crustal extension will be transitory.

\subsection{Development of Vent Alignments}

Change in lithostatic pressure also affects magmatism because magmas ascend by buoyant rise. The buoyancy forces acting on the magma are equivalent to the hydrostatic pressure gradient, given by Lister and Kerr [1991] as

$$
P_{h}=\int_{0}^{Z}\left[\rho_{\text {rock }}(z)-\rho_{\text {magma }}\right] g d z
$$

where $\rho_{\text {rock }}$ and $\rho_{\text {magma }}$ are density of rock and magma, respectively, $g$ is gravitational acceleration, and $Z$ is the depth of magma generation. Rock density varies as a function of depth, most dramatically at the Moho discontinuity. Because the density of magma is typically less than that of mantle but greater than that of most crustal rocks, a level of neutral magma buoyancy can exist in the crust. An isolated pod of magma above the level of neutral buoyancy will sink, and a pod below the level of neutral buoyancy will rise. Magmas fed by conduits respond to the integrated hydrostatic pressure along the conduit but tend to have flow characteristics responding to the local hydrostatic pressure. Thus dikes will tend to propagate laterally above the level of neutral buoyancy [Lister and Kerr, 1991], a phenomenon observed in eroded volcanic fields where dike systems are exposed [Delaney and Gartner, 1997]. The level of neutral buoyancy will be deeper in the crust in basins than beneath mountains because of the different densities of these areas. On the basis of this model, longer dikes, dike swarms, and vent alignments are expected to form in these alluvial basins than elsewhere. Pliocene and Quaternary Crater Flat alignments, the longest vent alignments in the region, formed in the deepest part of Crater Flat. Lathrop Wells, an isolated vent, and anomaly AAA, a comparatively short alignment of three vents, formed in a comparatively shallow part of the basin. Thus, from the perspective of volcanic hazards analysis, understanding of the change in lithostatic pressure across the region can help constrain areas of likely dike propagation and alignment development.

Virtually all cones in the YMR that have clearly defined relationships to faults lie on faults that have high dilation tendencies in the current stress orientation. This suggests that the distribution of high-dilation tendency faults may indicate where new volcanoes are able to erupt. Steeply dipping highdilation tendency faults in the YMR include many faults that bound the Yucca Mountain block. These faults include the Solitario Canyon fault, which hosted basaltic dike injection $\sim 11.7 \pm 0.3 \mathrm{Ma}$ [Smith et al., 1997], the Ghost Dance Fault, which bisects the repository from north to south, and the Bow Ridge fault, located east of the repository site (Figure 1). Some of these faults, particularly the Solitario Canyon fault, likely extend to the detachment at 5-10 km depth [Young et al., 1992; Ferrill et al., 1996; Ofoegbu and Ferrill, 1998]. Therefore these faults have the potential as serving as low-energy pathways for magma transport to the surface (Figures 5a-5f).

\subsection{Impact on Probability Estimates}

The overall range of probability values, $1 \times 10^{-8}$ to $1 \times$ $10^{-7}$, arises from the application of a variety of models and a range of parameter distributions. Incorporation of structural data into the hazards analysis changes our estimate of the expected distribution of future volcanic vents and increases our estimate of the probability of volcanism at the repository. New information can change these estimates. For example, Wer- 
nicke et al. [1998] speculated that regional recurrence rate $\lambda_{t}$ may be 1 order of magnitude greater than previously thought, on the basis of anomalous Global Positioning System (GPS)derived crustal strain rates they observed in the YMR. If true, this change in regional recurrence rate would increase the upper bound of the hazard estimate to $\sim 10^{-6} / \mathrm{yr}$. Although the magnitude of these GPS strain rates [Savage, 1998] and their interpretation in terms of hazard rates are debated [Connor et al., 1998], such data illustrate how hazard rates can be affected by improved understanding of the geology of the volcanic systems.

It is worthwhile to assess this $10^{-8}-10^{-7} / \mathrm{yr}$ range in light of regional patterns of volcanism. The western Great Basin, which includes the YMR, comprises at least 211 basaltic volcanoes $<2$ Ma within an $82,000 \mathrm{~km}^{2}$ region [Luedke and Smith, 1981]. Simply averaging activity across the western Great Basin during the last $2 \mathrm{Ma}$ yields a recurrence rate of $1.3 \times 10^{-9} / \mathrm{yr} /$ $\mathrm{km}^{2}$. On average, the annual probability of volcanism within any $5 \mathrm{~km}^{2}$ area (i.e., the effective area of the repository) is $6 \times$ $10^{-9}$. However, volcanism strongly clusters in the western Great Basin, and Yucca Mountain is part of one of the youngest of these volcano clusters. Reasonably conservative estimates for the probability of volcanic eruptions at the proposed Yucca Mountain site should exceed this average regional estimate. In this respect, probability estimates of $<10^{-8} / \mathrm{yr}$ [Crowe et al., 1983, 1992; Geomatrix Consultants, 1996; U.S. Department of Energy, 1998] are unrealistic.

Similarly, the probability of volcanism at the Yucca Mountain site can be compared to the most active basaltic volcanic fields in the continental United States. For example, recurrence rates in the Cima volcanic field, California, are on the order of $30 \mathrm{v} / \mathrm{Myr}$ [Turrin et al., 1985]. On the Colorado Plateau some volcanic fields experience similar recurrence rates [Conway et al., 1998; Condit and Connor, 1996]. The probability of a volcanic event centered within a $5 \mathrm{~km}^{2}$ area in one of these areas is on the order of $10^{-6}-10^{-5} / \mathrm{yr}$. Comparable rates of basaltic volcanism have not occurred during the PlioceneQuaternary in the YMR, with the possible exception of rates during the Pliocene in the Greenwater Range, in the southern YMR. It is reasonable that the probability estimates we calculate for volcanic eruptions at Yucca Mountain be substantially less than those estimated for these larger, more active volcanic fields.

Finally, it should be noted that the very small annual probability of volcanic eruptions at the Yucca Mountain site, $10^{-7}$ / $\mathrm{yr}$, must be viewed in light of the very long performance period of the proposed repository. Although remanded, the 1994 Code of Federal Regulations Title 10, Part 60.122 (available from the Office of the Federal Register, National Archives and Records Administration, Washington, D. C.) for siting a highlevel radioactive waste repository indicates that the effects of disruptive scenarios must be considered if their probability exceeds $10^{-4}$ in $10^{4}$ years. Thus the probability of $10^{-4}-10^{-3}$ for the planned $10^{4}$ year performance period of the repository is a significant deficiency of the site geology. The ultimate assessment of suitability of the Yucca Mountain site will be risk-based, calculated using the potential radiological dose to a hypothetical group of individuals, located $20 \mathrm{~km}$ from the site during the next $10^{4}$ years [U.S. National Research Council, 1995]. The effects of a volcanic eruption on repository performance and the risks associated with volcanism to this group need to be considered explicitly in evaluating suitability and expected performance of the Yucca Mountain site.

\section{Conclusions}

Geologic structure controls the distribution of basaltic volcanism in the YMR on three scales. Regionally, PlioceneQuaternary volcanism is limited to the Amargosa Trough, possibly as a result of partial melting of the lithosphere in response to extension across the BMF and Crater Flat basin. Subregionally, magnetic surveys show that NE trending vent alignments, 4-16 km in length, are prevalent in the YMR and that some reactivated through time. Locally, high-dilation tendency normal faults that bound and penetrate Yucca Mountain are typical of those that have hosted basaltic dike intrusions in the past. Based on these observations, probability estimates of volcanic disruption of the proposed repository are $10^{-8}-10^{-7} / \mathrm{yr}$.

\section{Appendix}

In an area of distributed volcanism, like the YMR, a volcanic hazard analysis starts with the null hypothesis that a volcanic event, such as the formation of a new basaltic volcano or vent alignment, will occur within some time interval $\Delta t$ and within the area of interest $\boldsymbol{A}$. One goal of volcanic hazards assessment is to quantify the confidence with which this null hypothesis may be rejected in favor of an alternate hypothesis that such a volcanic event will not occur [McBimey, 1992]. For volcanic events that may be individual vents or vent alignments,

$$
\begin{gathered}
P_{L}\left[L \geq l_{r}(\Phi), \varphi_{1} \leq \Phi \leq \varphi_{2}\right]=\int_{l_{r}(\Phi)}^{\infty} \int_{\varphi_{1}}^{\varphi_{2}} f_{L}(l) f_{\Phi}(\varphi) d \varphi d l, \\
P_{x y}=1-\exp \left(-\lambda_{i} \lambda_{x y} \Delta x \Delta y \Delta t\right),
\end{gathered}
$$

$P[$ volcanic eruptions within $(A, \Delta t)]$

$$
=\sum_{i=1}^{X} \sum_{j=1}^{Y} P_{x, y}\left(x_{i}, y_{j}\right) P_{L}\left(x_{i}, y_{j}\right)
$$

and $\lambda_{t}, \lambda_{x, y}, f_{L}(l)$, and $f_{\Phi}(\varphi)$ are estimated from past patterns of volcanism. Estimation of $\lambda_{x, y}$ is accomplished using a Gaussian kernel

$K(x, y)=\exp \left\{-\frac{1}{2}\left[\left(\frac{x-x_{\nu}}{h}\right)^{2}+\left(\frac{y-y_{\nu}}{h}\right)^{2}\right]\right\}$,

which here, for simplicity, integrates to $2 \pi h^{2}$ but strictly is normalized to integrate to unity. The smoothing parameter $h$ is equivalent to the standard deviation of the distribution. If $x$ and $y$ locations are on a rectangular grid, the probability density function based on the distribution of $N$ volcanoes is

$$
\hat{f}(x, y)=\frac{\Delta x \Delta y}{2 \pi h^{2} N} \sum_{i=1}^{N} K(x, y)
$$

The effectiveness of the kernel model and optimal values of $h$ can be deduced from the distribution of nearest-neighbor distances between existing volcanoes. The cumulative probability density function is

$\hat{F}(R)=\int_{0}^{2 \pi} \int_{0}^{R} \frac{2}{h(2 \pi)^{3 / 2}} \exp \left[-\frac{1}{2}\left(\frac{r^{2}}{h^{2}}\right)\right] d r d \theta$

and this function, calculated with various values of $h$, is compared to the observed vent or vent alignment distribution. Then 
$\lambda_{x, y}=\frac{1}{2 \pi h^{2} N} \sum_{\nu=1}^{N} \exp \left\{-\frac{1}{2}\left[\left(\frac{x-x_{\nu}}{h}\right)^{2}+\left(\frac{y-y_{\nu}}{h}\right)^{2}\right]\right\}$

Additional factors which affect the distribution of basaltic volcanism may be easily incorporated into the analysis. Such factors may include variations in crustal density (this paper) or lava geochemistry [Condit and Connor, 1996]. A probability density function $f_{T}(x, y)$ is defined on the basis of this information. For example, in our application, $f_{T}(x, y)$ was estimated on the basis of the average crustal density near the locations of existing basaltic vents. The Gaussian kernel is then modified to estimate the recurrence rate of volcanism:

$$
\begin{gathered}
Q_{\nu}=\frac{\sum_{i=1}^{X} \sum_{j=1}^{Y} K\left(x_{i}, y_{\jmath}\right)}{\sum_{i=1}^{X} \sum_{j=1}^{Y} f_{T}\left(x_{i}, y_{j}\right) K\left(x_{i}, y_{j}\right)}, \\
\lambda_{x, y}=\frac{1}{2 \pi h^{2} N} \sum_{\nu=1}^{N} Q_{v} f_{T}(x, y) K(x, y) .
\end{gathered}
$$

Introduction of the integrated weighting factor $Q_{\nu}$ assures that the integral of the modified Gaussian kernel for a single volcano over a large map extent $X, Y$ relative to the smoothing parameter $h$ will be unity and that probability will be redistributed on the basis of $f_{T}(x, y)$ in the vicinity of the volcano.

\section{Notation}

$A$ area for which hazard is estimated.

$X, Y$ geographic coordinate system, here used as distance east and north, respectively.

$x, y$ geographic coordinates.

$x_{\nu}, y_{\nu}$ geographic coordinates of the center of a volcanic event (volcanic vent or alignment).

$\Delta x, \Delta y \quad$ small change in the $X, Y$ directions, within which $\lambda_{x, y}$ is considered constant.

$\lambda$ annual recurrence rate of volcanic event in the entire magmatic system.

$\lambda_{x, y}$ spatial recurrence of volcanic event within a small region $\Delta x, \Delta y$, given a volcanic event in the magmatic system.

$P_{x, y}$ probability that an alignment will form, within an area $\Delta x, \Delta y$.

$P_{L}$ probability that a vent alignment centered within $\Delta x, \Delta y$ will intersect the area of interest $A$.

$f_{L}(l)$ probability density function of vent alignment half-length.

$f_{\Phi}(\varphi)$ probability density function of vent alignment azimuth.

$\varphi_{1}, \varphi_{2}$ range of vent alignment azimuths that would result in intersection of $A$.

$\Phi$ azimuth of the vent alignment.

$l_{r}(\Phi)$ distance of vent alignment center from the boundary of $A$ along $\Phi$.

$K(x, y)$ Gaussian kernel function.

$h$ smoothing coefficient in the Gaussian kernel.

$N$ total number of volcanic events (volcanic vents or vent alignments) in the magmatic system. $r$ distance from volcanic event (volcanic vent or geographic center of vent alignment).

$\theta$ azimuth to volcanic event.

$f_{T}(x, y)$ probability density function to weight $\lambda_{x, y}$ using additional information.

$Q_{\nu}$ integrated weighting factor.

Acknowledgments. The authors thank Steven Nelson, Steven Self, C.-H. Ho, and Larry McKague for their technical reviews and Eugene Smith for acting as Associate Editor for this manuscript. Annette Mandujano provided assistance preparing the manuscript. This paper was prepared as a result of work performed at the Center for Nuclear Waste Regulatory Analyses (CNWRA) for the U.S. Nuclear Regulatory Commission (NRC) under contract NRC-02-97-009. This paper is an independent product of the CNWRA and does not necessarily reflect the views or regulatory position of the NRC.

\section{References}

Anderson, D. L., Theory of the Earth, Blackwell Sci., Malden, Mass., 1989.

Asmerom, Y., S. B. Jacobsen, and B. P. Wernicke, Variations in magma source regions during large-scale continental extension, Death Valley region, western United States, Earth Planet. Sci. Lett., 125, 235-254, 1994.

Bacon, C. R., Time-predictable bimodal volcanism in the Coso Range, California, Geology, 10, 65-69, 1982.

Bergantz, G. W., and R. Dawes, Aspects of magma generation and ascent in continental lithosphere, in Magmatic Systems, edited by M. P. Ryan, pp. 291-317, Academic, San Diego, Calif., 1994.

Bradshaw, T. K., and E. I. Smith, Polygenetic Quaternary volcanism at Crater Flat, Nevada, J. Volcanol. Geotherm. Res., 63, 165-182, 1994.

Carr, W. J., Styles of extension in the Nevada test site region, southern Walker Lane belt, in Integrated Volcano-Tectonic and Detachment Fault Model, edited by B. P. Wernicke, Mem. Geol. Soc. Am., 176, 283-303, 1990.

Champion, D. E., Volcanic episodes near Yucca Mountain as determined by paleomagnetic studies at Lathrop Wells, Crater Flat, and Sleeping Butte, Nevada, paper presented at Second Annual International Conference on High-Level Radioactive Waste Management, Am. Nucl. Soc., La Grange Park, Ill., 1991.

Condit, C. D., and C. B. Connor, Recurrence rates of volcanism in basaltic volcanic fields: An example from the Sprongerville volcanic field, Arizona, Geol. Soc. Am. Bull., I08, 1225-1241, 1996.

Connor, C. B., Cinder cone clustering in the TransMexacan volcanıc belt: Structural and petrologic implications, J. Geophys. Res., 95, 19,395-19,405, 1990.

Connor, C. B., and B. E. Hill, Estimating the probability of volcanic disruption of the candidate Yucca Mountain repository using spatially and temporally nonhomogeneous Poisson models, paper presented at American Nuclear Society Focus ' 93 Meeting, La Grange Park, Ill., 1993.

Connor, C. B., and B. E. Hill, Three nonhomogeneous Poisson models for the probability of basaltic volcanism: Application to the Yucca Mountain region, Nevada, U.S.A., J. Geophys. Res., 100, 10,10710,125, 1995.

Connor, C. B., C. D. Condıt, L. S. Crumpler, and J. C. Aubele, Evidence of regional structural controls on vent distribution: Springerville volcanic field, Arızona, J. Geophys. Res., 97, 12,349-12,359, 1992.

Connor, C. B., S. Lane-Magsino, J. A. Stamatakos, R. H. Martin, P. C. La Femina, B. E. Hill, and S. Lieber, Magnetic surveys help reassess volcanic hazards at Yucca Mountain, Nevada, Eos Trans. $A G U$, 78(7), 73-78, 1997.

Connor, C. B., J. A. Stamatakos, D. A. Ferrill, and B. E. Hill, Detecting strain in the Yucca Mountain area (comment), Science, 282, pap. 1007b, 1998. (Available at http://www.sciencemag.org)

Conway, F. M., D. A. Ferrill, C. M. Hall, A. P. Morris, J. A. Stamatakos, C. B. Connor, A. N. Halliday, and C. Condit, Timing of basaltic volcanism along the Mesa Butte Fault in the San Francisco volcanic field, Arizona, from ${ }^{40} \mathrm{Ar} /{ }^{39} \mathrm{Ar}$ dates: Implications for longevity of cinder cone alignments, J. Geophys. Res., 102, 815-824, 1997.

Conway, F. M., C. B. Connor, B. E. Hill, C. D. Condit, K. Mullaney, and C. M. Hall, Recurrence rates of basaltic volcanism in SP cluster, San Francisco volcanic field, Arizona, Geology, 26, 655-658, 1998. 
Crowe, B. M., Basaltic volcanic episodes of the Yucca Mountain region, paper presented at High-Level Radioactive Waste Management, International Conference, Am. Nucl. Soc., Las Vegas, Nev., April 8-12, 1990.

Crowe, B. M., and F. V. Perry, Volcanic probability calculations for the Yucca Mountain site: Estimation of volcanic rates, paper presented at Nuclear Waste Isolation in the Unsaturated Zone, Focus '89, Am. Nucl. Soc., La Grange Park, Ill., 1989.

Crowe, B. M., D. T. Vaniman, and W. J. Carr, Status of volcanic hazard studies for the Nevada nuclear waste storage investigations, Los Alamos Natl. Lab. Rep. LA, LA-9325-MS, 1983.

Crowe, B. M., R. Morley, S. Wells, J. Geissman, E. McDonald, L. McFadden, F. Perry, M. Murrell, J. Poths, and S. Forman, The Lathrop Wells volcanic center: Status of field and geochronology studies, paper presented at Third International Conference on High-Level Radioactive Waste Management, Am. Nucl. Soc., La Grange Park, Ill., 1992.

Day, W. C., C. J. Potter, D. S. Sweetkind, R. P. Dickson, and C. A. San Juan, Bedrock geologic map of the central block area, Yucca Mountain, Nye County, Nevada, U.S. Geol. Surv. Misc. Invest. Ser. Map, I-2601, 1997.

Delaney, P. T., and A. E. Gartner, Physical processes of shallow dike emplacement near the San Rafael Swell, Utah, Geol. Soc. Am. Bull., 109, 1177-1192, 1997.

Eggler, D. H., The effect of $\mathrm{CO}_{2}$ upon partial melting of peridotite in the system $\mathrm{Na}_{2} \mathrm{O}-\mathrm{CaO}-\mathrm{Al}_{2} \mathrm{O}_{3}-\mathrm{MgO}-\mathrm{SiO}_{2}-\mathrm{CO}_{2}$ to $35 \mathrm{~Kb}$, with an analysis of melting in a peridotite- $\mathrm{H}_{2} \mathrm{O}-\mathrm{CO}_{2}$ system, $\mathrm{Am}$. J. Sci., 278, 305-343, 1978.

Farmer, G. L., F. V. Perry, S. Semken, B. Crowe, D. Curtis, and D. J. DePaolo, Isotopic evidence on the structure and origin of subcontinental lithospheric mantle in southern Nevada, J. Geophys. Res., 94, 7885-7898, 1989.

Faulds, J. E., and R. J. Varga, The role of accommodation zones and transfer zones in the regional segmentation of extended terrains, in Accommodation Zones and Transfer Zones: The Regional Segmentation of the Basin and Range Province, edited by J. E. Faulds and J. H. Stewart, Spec. Pap. Geol. Soc. Am., 323, 1-45, 1998.

Faulds, J. E., J. W. Bell, D. L. Feuerbach, and A. R. Ramelli, Geologic map of the Crater Flat area, Nevada, Map 101, Nev. Bur. of Mines and Geol., Reno, 1994.

Ferrill, D. A., J. A. Stamatakos, S. M. Jones, B. Rahe, H. L. McKague, R. H. Martin, and A. P. Morris, Quaternary slip history of the Bare Mountain fault (Nevada) from the morphology and distribution of alluvial fan deposits, Geology, 24, 559-562, 1996.

Ferrill, D. A., J. A. Stamatakos, and D. Sims, Normal fault corrugation: Implications for growth and seismicity of active normal faults, $J$. Struct. Geol., 21, 1027-1038, 1999.

Fleck, R. J., B. D. Turrin, D. A. Sawyer, R. G. Warren, D. E. Champion, M. R. Hudson, and S. A. Minor, Age and character of basaltic rocks of the Yucca Mountain region, southern Nevada, J. Geophys. Res., 101, 8205-8227, 1996.

Foland, K. A., and S. C. Bergman, Temporal and spatial distribution of basaltic volcanism in the Pancake and Reveille Ranges north of Yucca Mountain, paper presented at Third International Conference on High-Level Radioactive Waste Management, Am. Nucl. Soc., La Grange Park, Ill., 1992.

Fridrich, C. J., Tectonic evolution of the Crater Flat Basin, Yucca Mountain region, Nevada, in Cenozoic Basins of the Death Valley Region, edited by L. Wright and B. Troxel, Spec. Pap. Geol. Soc. Am., in press, 1999.

Fridrich, C. J., J. W. Whitney, M. R. Hudson, and B. M. Crowe, Late Cenozoic extension, vertical-axis rotation, and volcanism in the Crater Flat basin, southwest Nevada, in Cenozoic Basins of the Death Valley Region, edited by L. Wright and B. Troxel, Spec. Pap. Geol. Soc. Am., in press, 1999.

Frizzell, V. A., Jr., and J. Shulters, Geologic map of the Nevada test site, southern Nevada, U.S. Geol. Surv. Misc. Invest. Ser. Map, I-2046, 1990. Geomatrix Consultants, Probabilistic volcanic hazard analysis for Yucca Mountain, Nevada, Rep. BA0000000-1717-2200-00082, San Francisco, Calif., 1996.

Green, D. H., T. J. Falloon, and W. R. Taylor, Mantle-derived magmas: Roles of variable source peridotite and variable $\mathrm{C}-\mathrm{H}-\mathrm{O}$ fluid compositions, in Magmatic Processes: Physiochemical Principles, edited by B. O. Mysen, pp. 139-154, Geochem. Soc., University Park, Penn., 1987.

Gupta, V. K., and F. S. Grant, Mineral-exploration aspects of gravity and aeromagnetic surveys in the Sudbury-Cobalt area, Ontario, in The Utility of Regional Gravity and Magnetic Anomaly Maps, edited by W. J. Hinze, pp. 392-412, Soc. of Explor. Geophys., Tulsa, Okla., 1984.

Hamilton, W. B., Detachment faulting in the Death Valley Region, California and Nevada: Geologic and hydrologic investıgations of a potential nuclear waste disposal site at Yucca Mountain, southern Nevada, edited by M. D. Carr and J. C. Yount, U.S. Geol. Surv. Bull., 1790, 51-85, 1988.

Harry, D. L., and W. P. Leeman, Partial melting of melt metasomatized subcontinental mantle and the magma source potential of the lower lithosphere, J. Geophys. Res., 100, 10,255-10,269, 1995.

Hawkesworth, C., S. Turner, K. Gallagher, A. Hunter, T. Bradshaw, and $\mathrm{N}$. Rogers, Calc-alkaline magmatism, lithospheric thinning and extension in the Basin and Range, J. Geophys. Res., 100, 10,27110,286, 1995.

Heizler, M. T., F. V. Perry, B. M. Crowe, L. Peters, and R. Appelt, The age of Lathrop Wells volcano center: $\mathrm{An}{ }^{40} \mathrm{Ar} /{ }^{39} \mathrm{Ar}$ dating investigation, J. Geophys. Res., 104, 767-804, 1999.

Ho, C.-H., Time trend analysis of basaltic volcanism at the Yucca Mountain site, J. Volcanol. Geotherm. Res., 46, 61-72, 1991.

Ho, C.-H., Risk assessment for the Yucca Mountain high-level nuclear waste repository site: Estimation of volcanic disruption, Math. Geol., 24, 347-364, 1992.

Ho, C.-H., E. I. Smith, D. L. Feurbach, and T. R. Naumann, Eruptive probability calculation for the Yucca Mountain site, USA: Statistical estimation of recurrence rates, Bull. Volcanol, 54, 50-56, 1991.

Howard, N. W., Variation in properties of nuclear test areas and media at the Nevada test site, Lawrence Livermore Lab. Rep. UCRL, UCRL-53721, 1985.

Hudson, M. R., D. A. Sawyer, and R. G. Warren, Paleomagnetism and rotation constraints for the Miocene southwestern Nevada volcanic field, Tectonics, 13, 258-277, 1994.

International Atomic Energy Agency, Volcanoes and associated topics in relation to nuclear power plant siting, Provisional Safety Stand. Ser. 1, 49 pp., Vienna, Austria, 1997.

Jaques, A. L., and D. H. Green, Anhydrous melting of peridotite at $0-15 \mathrm{~kb}$ pressure and the genesis of tholeiitic basalts, Contrib. Mineral. Petrol., 73, 287-310, 1980.

Krauskopf, K. B., Radioactive waste disposal and geology, in Topics in the Earth Science, vol. 1, p. 143, Chapman and Hall, New York, 1988.

Lachenbruch, A. H., and P. Morgan, Continental extension, magmatism and elevation: Formal relations and rules of thumb, Tectonophysics, 174, 39-62, 1990.

Langenheim, V. E., Magnetic and gravity studies of buried volcanic centers in the Amargosa Desert and Crater Flat, southwest Nevada, U.S. Geol. Surv. Open File Rep., 95-564, 1995.

Langenheim, V. E., and D. A. Ponce, Depth to Pre-Cenozoic basement in southwest Nevada, paper presented at Sixth Annual International Conference on High-Level Radioactive Waste Management, Am. Nucl. Soc., La Grange Park, Ill., 1995.

Langenheim, V. E., K. S. Kirchoff-Stein, and H. W. Oliver, Geophysical investigations of buried volcanic centers near Yucca Mountain, southwest Nevada, paper presented at Fourth Annual International Conference on High-Level Radioactive Waste Management, Am. Nucl. Soc., La Grange Park, Ill., 1993.

Leeman, W. P., and J. G. Fitton, Magmatism associated with lithospheric extension: Introduction, J. Geophys. Res., 94, 7682-7684, 1989.

Lister, J. R., and R. C. Kerr, Fluid-mechanical models of crack propagation and their application to magma transport in dykes, J. Geophys. Res., 96, 10,049-10,077, 1991

Luedke, R. G., and R. L. Smith, Map showing distribution, composition, and age of Late Cenozoic volcanic centers in California and Nevada, U.S. Geol. Surv. Misc. Invest. Ser. Map, I-1091-C, 1981.

Luhr, J. F., J. J. Arana-Gomez, T. B. Housh, C. B. Connor, and J. A. Stamatakos, The Camargo volcanic field, Chihuahua, Mexico: PlioPleistocene extension-related basanites in the central Basin and Range Province (abstract), Eos Trans. $A G U, 78(46)$, Fall Meet. Suppl., F843, 1997.

Lutz, T. M., and J. T. Gutmann, An improved method for determining alignments of pointlike features and its implications for the Pinacate volcanic field, Sonora, Mexico, J. Geophys. Res., 100, 17,659-17,670, 1995.

Magsino, S. L., C. B. Connor, B. E. Hill, J. A. Stamatakos, P. C. La Femina, D. A. Sims, and R. H. Martin, CNWRA Ground magnetic 
surveys in the Yucca Mountain region, Nevada (1996-1997), CNWRA 98-001, Cent. for Nucl. Waste Regul. Anal., San Antonio, Tex., 1998.

Maldonaldo, F., Geologic map of Jackass Flats area, Nye County, Nevada, U.S. Geol. Surv. Misc. Invest. Ser. Map, I-1519, 1985.

McBirney, A. R., Volcanology, in Techniques for Determining Probabilities of Geologic Events and Processes, Stud. in Math. Geol., vol. 4, edited by R. L. Hunter and C. J. Mann, pp. 167-184, Oxford Univ. Press, New York, 1992.

McDuffie, S. M., C. B. Connor, and K. D. Mahrer, A simple 2-D stress model of dike-fracture interaction (abstract), Eos Trans. AGU, 75(16), Spring Meet. Suppl., 345, 1994.

McKague, H. L., Summary of measured medium properties of Paleozoic rocks at the DOE Nevada test site, Lawrence Livermore Lab. Rep. UCRL, UCRL-52884, 1980.

McKenzie, D., and M. J. Bickle, The volume and composition of melt generated by extension of the lithosphere, J. Petrol., 29, 625-679, 1988.

Morris, A., D. A. Ferrill, and D. B. Henderson, Slip-tendency analysis and fault reactivation, Geology, 23, 275-278, 1996.

Mysen, B. O., and A. L. Boettcher, Melting of a hydrous mantle, II, Geochemistry of crystals and liquids formed by anatexis of mantle peridotite at high pressures and high temperatures as a function of controlled activities of water, hydrogen, and carbon dioxide, $J$. Petrol., 16, 549-593, 1975.

Nakamura, K., Volcanoes as possible indicators of tectonic stress orientation: Principles and proposal, J. Volcanol. Geotherm. Res., 2, $1-16,1977$.

Ofoegbu, G. I., and D. A. Ferrill, Mechanical analysis of listric normal faulting with emphasis on seismicity assessment, Tectonophysics, 284 , 65-77, 1998.

O'Leary, D. W., Choosing a tectonic model for Yucca Mountain, Nevada (abstract), Geol. Soc. Am. Abstr. Programs, A192, 1996.

Parsons, T., and G. A. Thompson, The role of magma overpressure in suppressing earthquakes and topography: Worldwide examples, $S \mathrm{Ci}$ ence, 253, 1399-1402, 1991.

Pedersen, T., and H. E. Ro, Finite duration extension and decompression melting, Earth Planet. Sci. Lett., 113, 15-22, 1992.

Ponce, D. A., and H. W. Oliver, Gravity investigations, in Major Results of Geophysical Investigations at Yucca Mountain and Vicinity, Southern Nevada, edited by H. W. Oliver, D. A. Ponce, and W. C. Hunter, U.S. Geol. Surv. Open File Rep., 95-74, 1995.

Rahe, B., D. A. Ferrill, and A. P. Morris, Physical analog modeling of pull-apart basin evolution, Tectonophysics, 285, 21-40, 1997.

Rogers, N. W., C. J. Hawkesworth, and D. S. Ormerod, Late Cenozoic basaltic magmatism in the Western Great Basin, California and Nevada, J. Geophys. Res., 100, 10,287-10,301, 1995.

Rosenbaum, J. G., M. R. Hudson, and R. B. Scott, Paleomagnetic constraints on the geometry and timing of deformation at Yucca Mountain, Nevada, J. Geophys. Res., 96, 1963-1979, 1991.

Savage, J. C., Detecting strain in the Yucca Mountain area (comment), Science, 282, pap. 1007b, 1998. (Available at http://www.sciencemag. org)

Schweickert, R. A., and M. M. Lahren, Strike-slip fault system in the Amargosa Valley and Yucca Mountain, Nevada, Tectonophysics, 272, 25-41, 1997.

Scott, R. B., Tectonic setting of Yucca Mountain, southwest Nevada, in Basin and Range extensional tectonics near the latitude of Las Vegas, Nevada, in Integrated Volcano-Tectonic and Detachment Fault Model, edited by B. P. Wernicke, Mem. Geol. Soc. Am., 176, 251282, 1990.

Settle, M., The structure and emplacement of cinder cone fields, Am. J. Sci., 279, 1089-1107, 1979.

Sheridan, M. F., A Monte Carlo technique to estimate the probability of volcanic dikes, paper presented at Third International Conference on High-Level Radioactive Waste Management, Am. Nucl. Soc., La Grange Park, III., 1992.

Smith, E. I., D. L. Feuerbach, T. R. Naumann, and J. E. Faulds, The area of most recent volcanism about Yucca Mountain, Nevada: Implications for volcanic risk assessment, paper presented at International Nuclear Waste Symposium, Am. Nucl. Soc., Las Vegas, Nev., 1990.

Smith, E. I., S. Morikawa, and A. Sanchez, Summary of Activities of the Center for Volcanic and Tectonic Studies, Unvversity of Nevada, Las Vegas, for the Period 1986-1996, Nucl. Waste Proj. Off., Carson City, Nev., 1997.
Snow, J. K., and A. R. Prave, Covariance of structural and stratigraphic trends: Evidence for anticlockwise rotation within the Walker Lane Belt Death Valley region, California and Nevada, Tectonics, 13, 712-724, 1994.

Stamatakos, J. A., and D. A. Ferrill, Tectonic processes in the central Basin and Range region, in NRC High-Level Radioactive Waste Research at CNWRA, July-December 1995, CNWRA 95-02S, edited by B. Sagar, Cent. for Nucl. Waste Regul. Anal., 6-1-6-25, San Antonio, Tex., 1996.

Stamatakos, J. A., C. B. Connor, and R. H. Martin, Quaternary basin evolution and basaltic volcanism of Crater Flat, Nevada, from detailed ground magnetic surveys of the Little Cones, J. Geol., 105, 319-330, 1997a.

Stamatakos, J. A., C. B. Connor, B. E. Hill, S. Lane Magsino, and D. A. Ferrill, The Carrara fault in southwestern Nevada revealed from detailed gravity and magnetic results: Implications for seismicity, volcanism, and tectonics near Yucca Mountain, Nevada, Eos Trans. $A G U, 78(46)$, Fall. Meet. Suppl., F453, $1997 \mathrm{~b}$.

Takahashi, E., and I. Kushiro, Melting of a dry peridotite at high pressures and basalt magma genesis, Am. Mineral, 68, 859-879, 1983.

Tanaka, K. L., E. M. Shoemaker, G. E. Ulrich, and E. W. Wolfe, Migration of volcanism in the San Francisco volcanic field, Arizona, Geol. Soc. Am. Bull., 97, 129-141, 1986.

Turrin, B. D., J. C. Dohrenwend, R. E. Drake, and G. H. Curtis, K-Ar ages from the Cima volcanic field, eastern Mojave Desert, California, Isochron West, 44, 9-16, 1985.

U.S. Department of Energy, Repository safety strategy: U.S. Department of Energy's strategy to protect public health and safety after closure of a Yucca Mountain repository, YMP/96-012, 27 pp., U.S. Dep. of Energy, Washington, D. C., 1998.

U.S. National Research Council, Technical Bases for Yucca Mountain Standards, 206 pp., Natl. Acad. Press, Washington, D. C., 1995.

U.S. Nuclear Waste Technical Review Board, Report to the U.S. Congress and the Secretary of Energy, 1994 Findings and Recommendathons, 139 pp., U.S. Govt. Print. Off., Washington, D. C., 1994.

Vaniman, D. T., B. M. Crowe, and E. S. Gladney, Petrology and geochemistry of Hawaiite lavas from Crater Flat, Nevada, Contrib. Mineral. Petrol., 80, 341-357, 1982.

Wernicke, B., Cenozoic extensional tectonics of the U.S. cordillera, in The Cordilleran Orogen: Conterminous U.S., The Geology of North America, vol. G-3, edited by B. C. Burchfiel, P. W. Lipman, and M. L. Zoback, pp. 553-581, 1992.

Wernicke, B., J. L. Davis, R. A. Bennett, P. Elosegui, M. J. Abolins, R. J. Brady, M. A. House, N. A. Niemi, and J. K. Snow, Anomalous strain accumulation in the Yucca Mountain area, Nevada, Science, 279, 2096-2100, 1998.

Winograd, I. J., and W. Thordarson, Hydrogeologic and hydrochemical framework, south-central Great Basin, Nevada-California, with special reference to the Nevada test site, U.S. Geol. Surv. Prof. Pap., $712-2,1975$.

Yogodzinski, G. M., and E. I. Smith, Isotopic domains and the area of interest for volcanic hazard assessment in the Yucca Mountain area (abstract), Eos Trans. $A G U, 76(46)$, Fall Meet. Suppl., F669, 1995.

Young, S. R., G. L. Stirewalt, and A. P. Morris, Geometric models of faulting at Yucca Mountain, CNWRA 92-008, Cent. for Nucl. Waste Regul. Anal., San Antonio, Tex., 1992.

Zoback, M. L., State of stress in the northern Basin and Range Province, J. Geophys. Res., 94, 7105-7128, 1989.

C. B. Connor, D. A. Ferrill, B. E. Hill, G. I. Ofoegbu, B. Sagar, and J. A. Stamatakos, Center for Nuclear Waste Regulatory Analyses, Southwest Research Institute, 6220 Culebra Road, San Antonio, TX 78238-5166. (cconnor@swri.edu; dferrill@swri.edu; bhill@swri.edu; bsagar@ccfvax.ccf.swrı.edu; jstam@swri.edu)

F. M. Conway, Department of Physical Sciences, Western Arizona College, Yuma, AZ 85365-8834. (aw conway@awc.cc.az.us)

J. Trapp, Division of Waste Management, Office of Materials Safety and Safeguards, U.S. Nuclear Regulatory Commission, Mail Stop 7 C6, 2 White Flint North, 11545 Rockville Pike, Rockvılle, MD 20852-2738.

(Received August 28, 1998; revised September 30, 1999; accepted October 7, 1999.) 